\title{
Estimation of Future Generated Amount of E-Waste in the United States
}

\author{
Shoou-Yuh Chang, Godwin Appiah Assumaning, Yassir Abdelwahab \\ Department of Civil and Environmental Engineering, North Carolina A\&T State University, \\ Greensboro, NC, USA \\ Email: chang@ncat.edu, godwinappiah30@yahoo.com, yassir71@gmail.com
}

Received 14 July 2015; accepted 25 August 2015; published 28 August 2015

Copyright (C) 2015 by authors and Scientific Research Publishing Inc.

This work is licensed under the Creative Commons Attribution International License (CC BY). http://creativecommons.org/licenses/by/4.0/

\section{Abstract}

Electrical and electronic equipment waste, or e-waste, is one of the fastest growing waste streams in the United States. The main objective of this study is to estimate the future quantities of e-waste of thirteen selected electric and electronic products in the United States in 2025. To estimate the future amount of e-waste, the authors performed a material flow analysis. The model inputs are historical and future product sales data and the product's average life span. Sensitivity analysis was constructed to evaluate the effect of the model inputs (average life span and future sales data) in the generation of e-waste. The results show that about 1.0835 billion units will reach their end of life (EOL) in 2025; cell phone devices are the highest occurring product among the thirteen selected products and weighted for about $66.0 \%$ of units of the total amount, followed by computer products at $18.0 \%$, TV products at $11.6 \%$, computer monitors at $1.7 \%$, hard copy peripherals (HCP) at $1.6 \%$, and computer accessories at $1.0 \%$. The sensitivity analysis shows that the product life span has an effect on the e-waste generation amounts from the products under study, while the sensitivity analysis of forecasted future sales indicates that the generated waste will increase or decrease according to the sales trend.

\section{Keywords}

E-Waste, Material Flow Analysis, United States, Estimation

\section{Introduction}

Waste of electrical and electronic equipment, or e-waste, is one of the fastest growing municipal solid waste streams due to continuous technology innovation and high demand from consumers. About $70 \%$ of the heavy 
metals found in US landfills come from electronic discards. Managing e-waste has become a major challenge in many developing countries. It is expected that the amount of e-waste will increase between $16 \%$ - $28 \%$ every year [1]. The challenge faced in e-waste management is not only the growing quantities of waste but also the complexity of e-waste. E-waste is one of the most complex waste streams because of the wide variety of products ranging from mechanical devices to highly integrated systems and rapid change in the products' design [2]. Electrical and electronic products are an integration of numerous modern technologies and are composed of many different materials and components. The composition of the electrical waste and electronic equipment depends on each item that composes it; it can be divided into six categories [3].

1) Iron and steel, used in cabinets and frames.

2) Non-ferrous metals, above all copper used in cables.

3) Glass, used in screens and displays.

4) Plastic, used in cabinets, cables coating and circuit boards.

5) Electronic components mounted on circuit boards.

6) Others, such as rubber, wood, ceramics, etc.

E-waste accounts for approximately $1 \%-2 \%$ of the municipal solid waste stream in the United States. But it garners a great deal of interest for several reasons [4].

1) Rapid growth and change in this product sector, leading to a constant stream of new product offerings and a wide array of used products needing appropriate management.

2) The intensive energy and diverse material inputs that go into manufacturing electronic products represent a high degree of embodied energy and scarce resources, many of which can be recovered.

3) The presence of substances of concern in some electronics, particularly older products, which merit greater consideration for safe, EOL management.

4) The opportunities for resource conservation and recovery through improved collection and recycling of electronics.

Consumer electronics have become increasingly popular and culturally important over the past several decades, changing how we communicate, entertain ourselves, get information, and the speed with which we do so. As the nature, use, and number of electronic products change over time, patterns of sales, storage, and EOL management also change. Waste managers, manufacturers, and policymakers need reliable and current information to inform and improve the management of used electronics [4].

Traditionally, there have been several approaches to estimate or quantify the amount of e-waste generated in developing countries. The practical way is to roughly estimate the waste amount based on the sales and the life span of the products, which is known as the market supply model (Carnegie Mellon method). The market supply method, which requires the historical sales data combined with the average life span of the products, is widely used to estimate e-waste [1] [2] [5] [6], which is used in this study. There are other models used to estimate e-waste amounts, such as the time step model, leaching model, market supply model, distribution delay, and stock and life span model, and each model requires different input data

In the present situation, there is still a need for more accurate information on the electrical and electronic equipment put on the market as well as the quantity of e-waste generated and disposed each year. The situation is more or less the same in all countries. There are at least two factors influencing the amount of the e-waste.

1) The quantity of the products put on the market (sales data).

2) Life span of the product.

\section{Literature Review}

The authors developed a mathematical framework to estimate the future outflows and infrastructure needed to recycle personal computer systems in California [2]. In addition to that, the authors estimated the total cost of ewaste recycling in California. He used the time-series material flow analysis model in the study. The study indicated that the inflow pattern and amount had a great impact on the outflow pattern and amount for computer systems. According to the authors the availability of accurate data had a great impact in the model result, especially the life span of the products. The authors showed that the State of California has to establish more recovery facilities after the year 2005 in order to recycle the computer systems in a proper way.

Acording to [7], the authors estimated the amount of waste electrical and electronic equipment (WEEE) using 
a material flow analysis for seven selected items: refrigerators, freezers, washing machines, televisions, audio systems, computers, and cell phones, the authors used this metrics, because they are the most representative of the WEEE considering, the weight, sales volume, lifetime, presence and importance of hazardous substances. The model assumptions were based on two types of markets: mature market for products such as refrigerators, freezers, washing machines, televisions, and audio systems and non-mature market for computers and cell phones because of the technological changes affecting life span. The model inputs were sales data and the stock in use for the products. The model result shows that the average life span is not constant for such products as computers and cell phones.

A time-step model developed to estimate the generation e-waste amount in Japan by [8]. The model inputs were average life span and the product's weight. The result of this study indicated that the waste weight of four of the items, air conditioners, collecting cathode ray tube (CRT) TV sets, refrigerators, and washing machines were larger than any of the other items in this study. There are some items for which the stock increased or decreased: for example, the waste amount of items such as CRT TVs, VCRs, and CRT displays was larger than the domestic shipment amount, and their stock decreased. This is due to drastic replacement by liquid-crystal display (LCD) or plasma display TVs and DVD players during that period. On the other hand, the waste amount of items such as DVD players, LCD displays, and printers was smaller than the domestic shipment amount. This is because these items have been growing in volume.

An approach and methodology constructed to estimate the future outflows of the electrical and electronic waste in India by [1]. He used a time series, multiple life span, and EOL model. The model estimates future e-waste generation by modeling the electrical and electronic equipment usage and disposal. The result of the study indicates that the influence of WEEE estimated is the inflow amount (sales data) and the first-user decision. In addition to that, the accuracy of the model result is dependent on how accurate the available data are and the assumptions on the average life span of the products.

A paper published by [9] discussed two different approach types of material flow models: delay model and leaching model. The leaching model is where the estimation of the present outflow can be derived from the size of the present stock. This means that the amount of outflow is considered to be equal to a fraction of the stock. The advantages of this model are that it does not require more data and it is easy for calculation. In the delay model (dynamic model), the outflow in a certain year is equal to or a function of the inflow in the past because the material is disposed after it has worn out, gone out of fashion, or is no longer compatible with other products. The model required the life span of the product and historical data.

Material flow analysis for five pieces of household electrical and electronic equipment, namely televisions, washing machines, air conditioners, refrigerators, and personal computers to constructed to estimate the e-waste quantity by [10]. The result shows an increase in e-waste generation from both households and business sectors in study area. In the field study, the authors found that the recyclers are not recycling CRT televisions larger than 21 inches because they have been replaced by LCD televisions. The author observed many risks during this study toward workers who are unaware of the risks involved in handling the e-waste. The author also observed other activities such as burning and dismantling the e-waste in agricultural lands. The best solution to handle the e-waste problems is setting up manufacturer take-back and establishing a solid recycling system.

A study covered five main kinds of electrical and electronic equipment (televisions, refrigerators, washing machines, air conditioners, and personal computers) from households performed by [11]. The authors used material flow analysis methodology to predict the amount of e-waste generation for the five selected products. A new product item is purchased and becomes obsolete after some time. The owner has four options. First, the owner can donate the products to others to reuse it for some time. Second, the owner may store it at home. Third, the owner could sell it or donate it to recycling collectors. Fourth, the owner can dispose of it directly as municipal solid waste. The authors used polynomial regression analysis to obtain the amount of appliances in the future using statistical data for the number of the households in the study area.

Material flow analysis performed by [6] in order to estimate the future amount of e-waste in the study area. The authors selected Microsoft Excel software to generate the calculation. The authors used polynomial regression analysis to estimate the future sales amount by choosing the best-fit line with a high R-square value.

Export of e-waste study by [12]. The approach is based on a combination of a material flow analysis and survey data from residential and business sectors. The methodology is implemented on desktops and laptops. The authors made a number of assumptions in order to implement the material flow analysis methodology.

Models are powerful tools for simulating and can save money and time; therefore, the accuracy of the models 
is important [13]. There are many model verification methods such as

1) Model evaluation statistics (dimensional).

2) Model evolution statistics (standard regression).

3) Model evaluation statistics (error index).

\section{Methodology}

It is important to know the amount of the e-waste that will be generated and when it will be generated in order to establish appropriate infrastructures. The authors performed a material flow analysis model in this study to calculate the future e-waste amount in the United States. The model was based on the assumptions of the life span and historical and future sales data for thirteen selected electronic products. The recycled and disposed amount to be generated in the future was calculated based on the EOL quantity with assumptions in their percentages, which is the same model concept used by the United States Environmental Protection Agency (USEPA) in its reports for 2007, 2008, and 2011 to estimate the amount of e-waste generated in 2007, 2008, and 2009 [4] [14], [15]. Estimation of the future amount of products to be collected for EOL management required forecasting the future sales. In order to calculate the future sales amount, the authors constructed two methods: The first method was used for items whose sales rates were decreasing, and the second method was polynomial regression analysis [6]. The last part of the methodology is the sensitivity analysis to evaluate the effect of the life span and predicted sales amounts in EOL management.

\subsection{Model Input Data}

The model inputs are the sales data (historical and future sales data) and the life spans of the products. The authors used input sales data from 1980 to 2010 data can be found in Appendix Table A1 and Appendix Table A2 [4].

The authors used two methods, to estimate the future quantity of the product's sales amount. The first method used was for items, whose sales were decreasing annually, such as desktops, color TVs, (HCP), projectors, monochrome, keyboards, and mice. The authors calculated the average decreasing rate using sales data from 2007 and 2010 as shown in "Equation (1)". The decreasing rate for those items is assumed fixed and will not change, which in reality is not true, but as this method is an approximation analysis, the authors made this assumption. Table 1 shows the items and their decreasing annual rate. The authors used the annual decreasing rate $\left(\mathrm{R}_{\mathrm{P}}\right)$ to calculate the future sales for the products from 2011 to 2025 using the following Equation (2). Predicted sales amount for these seven products presented in Appendix Table $\mathbf{B}$.

The second method is polynomial regression analysis, and the authors used this method in items whose sales rates were increasing such as laptops, cell phones, and flat panel TVs [6]. The authors extrapolated quantities of these three items' sales data from 2001-2010 to 2025 using the most appropriate trend lines, as shown in Figures 1-3, and the actual values given in Table 2.

$$
R_{P}=\frac{S_{(2010)}-S_{(2007)}}{S_{(2010)}}
$$

where, $R_{p}=$ Annual decreasing rate. $S_{2010}=$ Sales amount in 2010. $S_{2007}=$ Sales amount in 2007

$$
S_{(Y+1)}=\left(S_{(Y)} \times R_{P}\right)+S_{Y}
$$

where, $S_{y}=$ Sales amount in year $(y) \cdot S_{y+1}=$ Sales amount in year $(y+1) \cdot R_{p}=$ Annual decreasing rate. Appendix Table B shows the products and their sales amount from 2011 to 2025. Calculation based on Equation (2).

\subsection{Products Life Span}

The life span of the product, or when the product reaches the end of its life, it is very difficult to assume because it depends on many factors such as user behavior, age, gender, etc. The life span of the products used in this study was adopted from the USEPA with some changes. The total life span of any particular product will encompass several stages of use. The "first use" is the time period in which the product was considered functional to the first purchaser. When the product ceases to be functional to the first user, the product may be put in storage, discarded, or recycled. If it is in working order, however, someone else will most likely reuse it. This is 


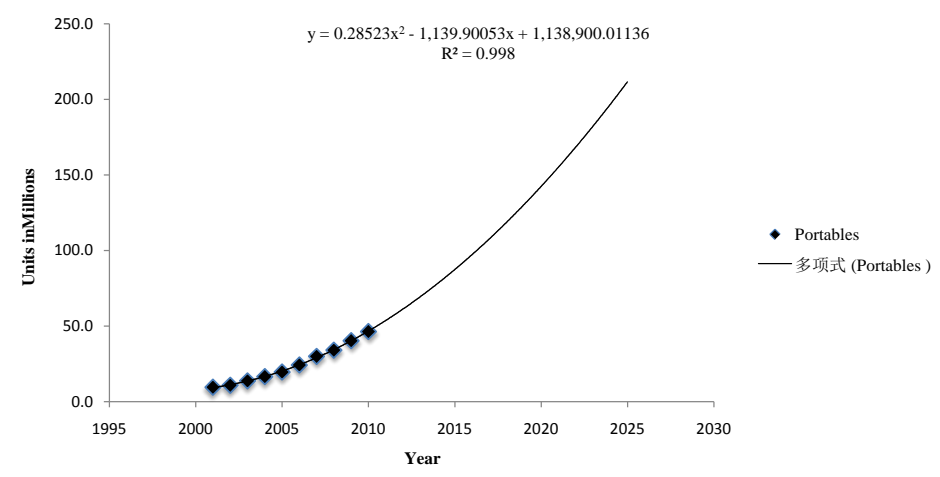

Figure 1. Polynomial regression analysis for portables computers.

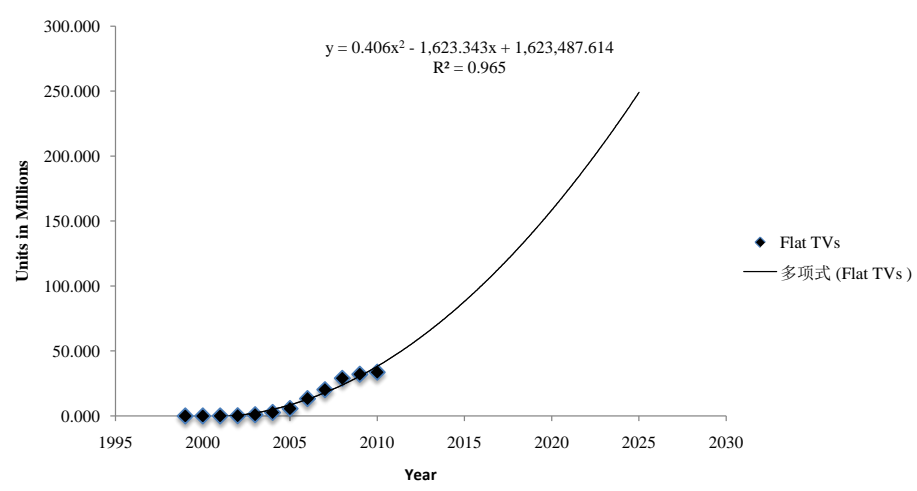

Figure 2. Polynomial regression analyses for flat panel TVs.

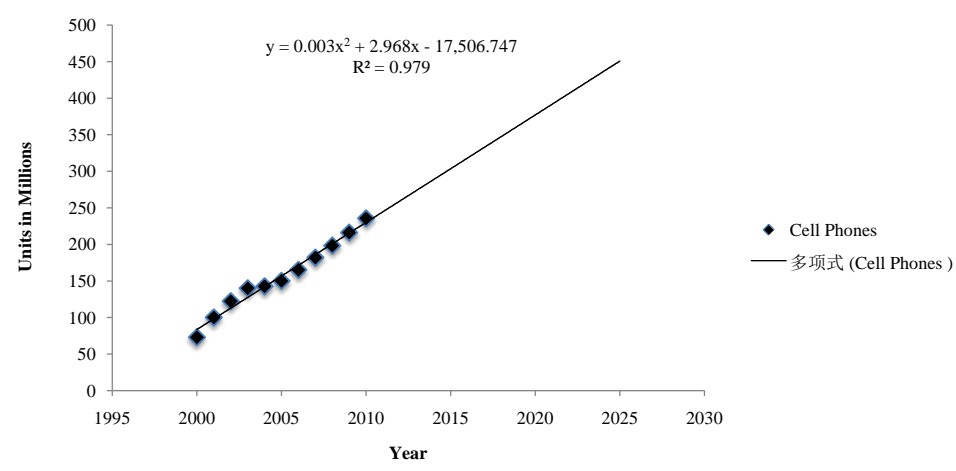

Figure 3. Polynomial regression analyses for cell phones.

Table 1. Annual decreasing rate for the products that their sales are decreasing annually.

\begin{tabular}{cc}
\hline Product & Annual decreasing rate $\left(\boldsymbol{R}_{\boldsymbol{P}}\right) \%$ \\
\hline Desktops & -0.10 \\
Color TVs $>19$ inches & -0.33 \\
Color TVs $<19$ inches & -0.32 \\
Hard copy peripherals & -0.14 \\
Projections & -0.42 \\
Monochrome. & -0.29 \\
Keyboards and mice & -0.15 \\
\hline
\end{tabular}


Table 2. Predicted sales amounts for portables computers, flat TVs, and cell phones.

\begin{tabular}{llll}
\hline Year & Portables & Flat TVs & Cell phones \\
\hline & & Units in millions & \\
\hline 2011 & 55.5 & 46.4 & 264.5 \\
2012 & 63.1 & 55.5 & 287.2 \\
2013 & 71.2 & 65.4 & 310.9 \\
2014 & 79.9 & 76.0 & 335.4 \\
2015 & 89.2 & 87.5 & 360.9 \\
2016 & 99.0 & 99.7 & 387.3 \\
2017 & 109.5 & 112.8 & 414.5 \\
2018 & 120.5 & 126.6 & 442.7 \\
2019 & 132.0 & 141.2 & 471.8 \\
2020 & 144.2 & 156.6 & 501.9 \\
2021 & 156.9 & 172.8 & 532.8 \\
2022 & 170.1 & 189.8 & 564.6 \\
2023 & 184.0 & 207.6 & 597.4 \\
2024 & 198.4 & 226.2 & 631.0 \\
\hline
\end{tabular}

referred to as the "second use" stage. There are many combinations of use, reuse, and storage underlying the second use stage before the last user is ready for EOL management of the product. "Appendix Table C" shows the assumed life span for the products and the percentage from the sales amount when the products reach their EOL.

\subsection{Model Applied}

In a socioeconomic system, products flow into the society (sales) and then accumulate in the built environment (stock); when reaching EOL after a certain period (life span), they flow out. The model presented in this study tries to estimate the future amount of e-waste in the United States. The model is a material flow analysis model, which is widely used to estimate the amount of waste in current years or to predict the waste that will be generated in the future. The model inputs are the annual product sales data, historical sales data, and future sales data, which are predicted using the sales rate for the items whose sales are decreasing annually and polynomial regression analysis for the items whose annual sales are increasing.

In material flow analysis, the general form used to represent the outflow after the useful life span is a function of the inflow in the past and can be expressed by Equation (3).

$$
\text { outflow }=\sum_{i} \text { inflow } \times P
$$

where the outflow represents the waste generated and the inflow represent the sales amount and $(P)$ is the percentage amount when the product reaches its end of life. Equations (4) and (5) show how the generated e-waste amount for desktops and portable computers are calculated.

$$
W_{(D C)_{n}}=\sum_{i=7,9,12,15}\left(S_{n-7}\right) \times(25 \%)+\left(S_{n-9}\right) \times(25 \%)+\left(S_{n-12}\right) \times(25 \%)+\left(S_{n-15}\right) \times(25 \%)
$$

where,

$W_{(D C)_{n}}=$ The amount of EOL generated from desktop computer products in year $(n) . S=$ historical and future sales amount for desktops product. 


$$
W_{(P C)_{n}}=\sum_{i=3,5,6,7}\left(S_{n-3}\right) \times(20 \%)+\left(S_{n-5}\right) \times(20 \%)+\left(S_{n-6}\right) \times(30 \%)+\left(S_{n-7}\right) \times(30 \%)
$$

where,

$W_{(P C)_{n}}=$ The amount of EOL collected from portable computer products in year $(n) . S=$ historical and future sales amount for portable computers product.

The amount collected for EOL management for CRT TVs product estimated by Equation (6).

$$
W_{(C T V)_{n}}=\sum_{i=8,11,15,17}\left(S_{n-8}\right) \times(25 \%)+\left(S_{n-11}\right) \times(25 \%)+\left(S_{n-15}\right) \times(25 \%)+\left(S_{n-17}\right) \times(25 \%)
$$

where,

$W_{(C T V)}=$ The amount collected for EOL management from CRT TV products in year $(n) . S=$ historical and future sales amount for PC flat panel monitors.

Equation (7) for CRT PC monitor products to calculate the quantity collected for EOL management.

$$
W_{(C M)_{n}}=\sum_{i=5,5,8,10,13}\left(S_{n-5}\right) \times(25 \%)+\left(S_{n-8}\right) \times(25 \%)+\left(S_{n-10}\right) \times(25 \%)+\left(S_{n-13}\right) \times(25 \%)
$$

where,

$W_{(C M)_{n}}=$ The EOL amount for CRT PC monitor products in year $(n) . S=$ historical and future sales amount for CRT PC monitors.

Equation (8) calculates the amount collected for EOL management from PC flat monitor products.

$$
W_{(F M)_{n}}=\sum_{i=9,910,11}\left(S_{n-9}\right) \times(80 \%)+\left(S_{n-10}\right) \times(10 \%)+\left(S_{n-10}\right) \times(25 \%)+\left(S_{n-11}\right) \times(10 \%)
$$

where,

$W_{(F M)_{n}}=$ The EOL for PC flat monitor products in year $(n) . S=$ historical and future sales amount for PC flat panel monitors.

The EOL amount generated from hard copy peripherals product calculated by Equation (9).

$$
W_{(H C P)_{n}}=\sum_{i=4,7,10,14}\left(S_{n-4}\right) \times(25 \%)+\left(S_{n-7}\right) \times(25 \%)+\left(S_{n-10}\right) \times(25 \%)+\left(S_{n-14}\right) \times(25 \%)
$$

where,

$W_{(H C P)_{n}}=$ The amount collected for EOL management from HCP in year $(n) . S=$ historical and future sales amount for Hard Copy Peripherals

The EOL quantity results from using keyboard products estimated by Equation (10).

$$
W_{(K)_{n}}=\sum_{i=4,5}\left(S_{n-4}\right) \times(90 \%)+\left(S_{n-5}\right) \times(10 \%)
$$

where,

$W_{(K B)_{n}}=$ The amount collected for EOL management from key board products in year $(n) . S=$ historical and future săles amount for keyboard products.

The EOL quantity results from using mice products estimated by Equation (11)

$$
W_{(M)_{n}}=\sum_{i=4,5}\left(S_{n-4}\right) \times(90 \%)+\left(S_{n-5}\right) \times(10 \%)
$$

where,

$W_{(M)_{n}}=$ The amount collected for EOL management from mice products in year $(n) . S=$ historical and future sales amount for keyboard products.

Equation (11) estimates the future EOL amount for projector and monochrome products.

$$
W_{(P R, M O N)_{n}}=\sum_{i=8,9,10}\left(S_{n-8}\right) \times(80 \%)+\left(S_{n-9}\right) \times(10 \%)+\left(S_{n-10}\right) \times(10 \%)
$$

where,

$W_{(P R, M O N)_{n}}=$ The amount collected for EOL management from projections and monochrome in year $(n) . S=$ historical and future sales amount for projections and monochrome.

Equation (11) is used to calculate the future quantity of e-waste generated by cell phone devices 


$$
W_{(C P)_{n}}=\sum_{i=2,5,6}\left(S_{n-2}\right) \times(65 \%)+\left(S_{n-5}\right) \times(30 \%)+\left(S_{n-6}\right) \times(5 \%)
$$

where,

$W_{(C P)_{n}}=$ The amount collected for EOL management from cell phone devices in year $(n) . S=$ historical and future săles amount for cell phones.

\subsection{Model Uncertainty}

The authors used the coefficient of determination to assess the predictive power of the model. The $R^{2}$ is computed as shown in Equation (14). The coefficient of determination, denoted $R^{2}$ or $r^{2}$ and pronounced R-squared, is a number that indicates how well data fit a statistical model. It is a statistic used in the context of a statistic model whose main purpose is either the prediction of future outcomes or the testing of hypotheses. On the basis of other related information, it provides a measure of how well observed outcomes are replicated by the model as the proportion of total variation of outcomes explained by the model. $R^{2}$ is a statistic that will give some information about the goodness of fit of a model. In regression, the $R^{2}$ coefficient of determination is a statistical measure of how well the regression line approximates the real data points. An $R^{2}$ of 1 indicates that the regression line perfectly fits the data. The authors collected observation data from the USEPA [15]. The observation data is the total amount collected for EOL management from 1999 to 2007. Observation and predicted data can be found in Table 3. Figure 4 shows the predicted result against the observation data from 1999 through 2007 with an $R^{2}$ value of 9.4.

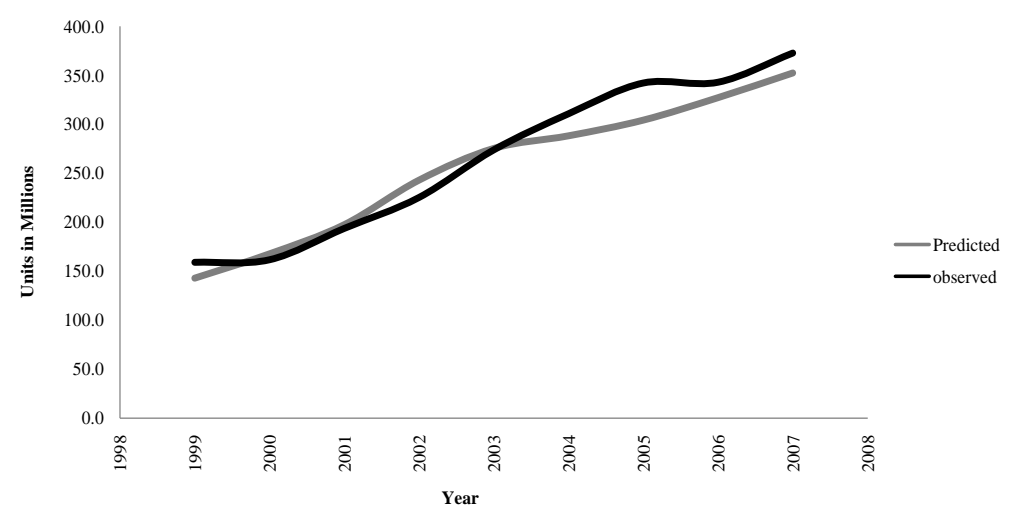

Figure 4. Model uncertainties, observation data against the predicted result.

Table 3. Observation and predicted data used to calculate the $R^{2}$ value.

\begin{tabular}{|c|c|c|}
\hline \multirow{2}{*}{ Year } & Observation data ${ }^{*}$ & Predicted data* \\
\hline & \multicolumn{2}{|c|}{ Units in millions } \\
\hline 1999 & 159.0 & 142.9 \\
\hline 2000 & 161.6 & 167.7 \\
\hline 2001 & 193.6 & 197.5 \\
\hline 2002 & 225.2 & 243.0 \\
\hline 2003 & 273.8 & 275.4 \\
\hline 2004 & 310.7 & 288.3 \\
\hline 2005 & 342.1 & 304.3 \\
\hline 2006 & 342.9 & 327.2 \\
\hline 2007 & 372.7 & 352.5 \\
\hline
\end{tabular}

\footnotetext{
${ }^{*}$ Total amount collect for EOL management for all products.
} 


$$
R^{2}=1-\left(\frac{\sum_{1}^{n}\left(Y^{\text {obser }}-Y^{\text {obser-mean }}\right)^{2}}{\sum_{1}^{n}\left(Y^{\text {obser }}-\hat{Y}\right)^{2}}\right)
$$

\subsection{Recycling and Disposed Amount}

To estimate the portion of the recycled amount in the future three methods evaluated; moving average, linear regression and exponential smoothing, based on data from USEPA from 1999 through 2007, and to evaluate which method is best among all, coefficient of determination $\left(R^{2}\right)$, mean absolute error (MAE) and root mean square error (RMSE) performed, values can be found in Table 4. Based on the result for the above three evolution methods moving average found to be the best in terms of error forecasting and used to predict the percentage of the recycling amount in the future as shown in Table 5 from total amount collected for EOL management every year from 2013 through 2025, and the generated quantity that will be disposed calculated by subtracted the amount estimated to be recycled from the total estimated amount collected for EOL management.

\subsection{Sensitivity Analysis}

This study presents a sensitivity analysis for the model input, product life span, and predicted sales amount. It analyzes sensitivity analysis for product life span for three selected products: flat panel TVs, portable computers,

Table 4. $R^{2}$, MAE and RMSE values for the moving average, linear regression and exponential smoothing methods used to forecast the future recycling percentage.

\begin{tabular}{cccc}
\hline Model & $R^{2}$ & MAE & RMSE \\
\hline Moving Average & 0.85 & 0.42 & 0.53 \\
Linear Regression & 0.74 & 0.61 & 0.67 \\
Exponential Smoothing & 0.51 & 0.72 & 0.95 \\
\hline
\end{tabular}

Table 5. Recycling percentage assmptions.

\begin{tabular}{lcccccc}
\hline \multirow{2}{*}{ Year } & Computers $^{*}$ & Pc Monitors & HCP & Keyboards \& mice & TVs $^{* * *}$ & Cell phones \\
\cline { 2 - 6 } & & & $\%$ & & \\
2013 & 39.2 & 30.9 & 33.6 & 9.0 & 16.9 & 11.7 \\
2014 & 38.9 & 30.2 & 33.7 & 8.7 & 16.8 & 11.9 \\
2015 & 39.0 & 30.5 & 33.7 & 8.8 & 16.8 & 12.1 \\
2016 & 39.0 & 30.6 & 33.7 & 8.9 & 16.8 & 12.4 \\
2017 & 39.0 & 30.4 & 33.7 & 8.8 & 16.8 & 12.6 \\
2018 & 39.0 & 30.5 & 33.7 & 8.8 & 16.8 & 12.9 \\
2019 & 39.0 & 30.5 & 33.7 & 8.8 & 16.8 & 13.1 \\
2020 & 39.0 & 30.5 & 33.7 & 8.8 & 16.8 & 13.4 \\
2021 & 39.0 & 30.5 & 33.7 & 8.8 & 16.8 & 14.7 \\
2023 & 39.0 & 30.5 & 33.7 & 8.8 & 16.8 & 14.2 \\
2024 & 39.0 & 30.5 & 33.7 & 8.8 & 16.8 & 14.5 \\
\hline 2025 & 39.0 & 30.5 & 33.7 & 8.8 & 8.8 & 16.8 \\
\hline
\end{tabular}

${ }^{*}$ Desktops \& portable computers, ${ }^{* *} \mathrm{CRT} \&$ flat monitors, ${ }^{* * *} \mathrm{CRT}$ TVs, flat TVs, projections and monochrome. 
and cell phones. According to the literature review, the life span has great influence on the amount of generated waste. This analysis indicates the importance of the life span, the corresponding need for comprehensive knowledge of consumer behavior, and the factors that affect the disposal decision such as technological innovation, availability, and cost of maintenance, among others. The idea is to increase the life span of those products by three years for portable computers and flat panel TVs, and two years for cell phones, and run the model to show how the generation of e-waste is affected by this change. The study presents a sensitivity analysis for product's predicted sales amount to study the effect of the uncertainty of the predicted sales amount in the e-waste generated quantity. The idea is to increase or decrease the prediction sales amount by $10 \%$.

The results for products life span sensitivity analysis shows that the amount of waste will decrease as presented in Figures 5-7 and Tables 6-8.

Sensitivity analysis constructed for the predicted sales data in this study to evaluate the uncertainty of the model. Assumed the predicted sales data will increase or decrease by $10 \%$. Result shown in Tables 9-11, indicted that the amount will be collected for EOL management will increase or decrease by the same amount of increasing in sales data in the future. Therefore the flow of the product in the market has a great influence in the waste amount as well as the accuracy of the sales data.

\section{Results}

\subsection{End of Life Management Amount}

Figure 8 shows the model result for amount collected for the EOL management from desktop computer products. The result shows that the e-waste generated from this product is decreasing due to high increasing number of laptop user's in recent years. The results indicated that about 15.6 million units could possible to be collected for end of life management in 2025.

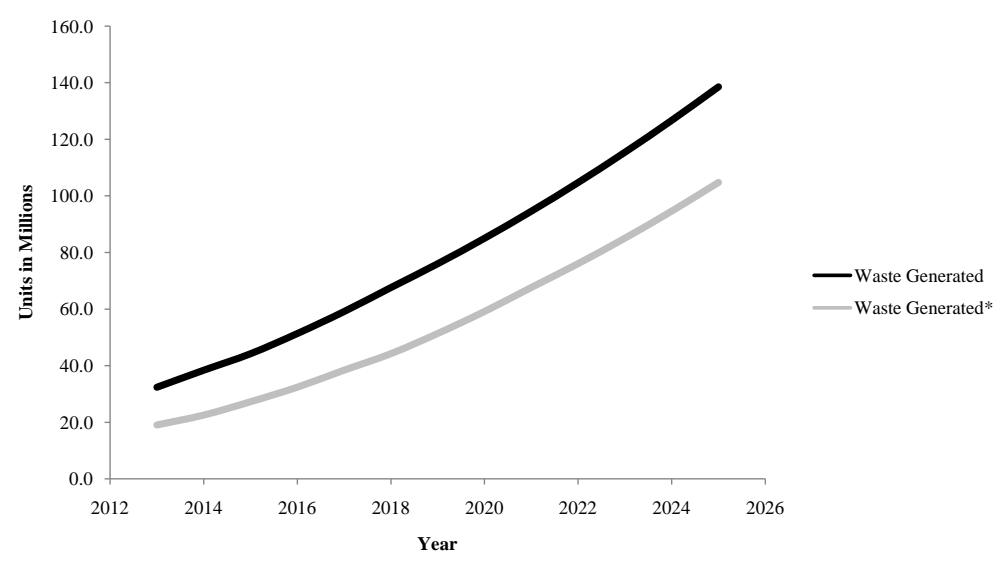

Figure 5. Sensitivity analysis for portable computers life span.

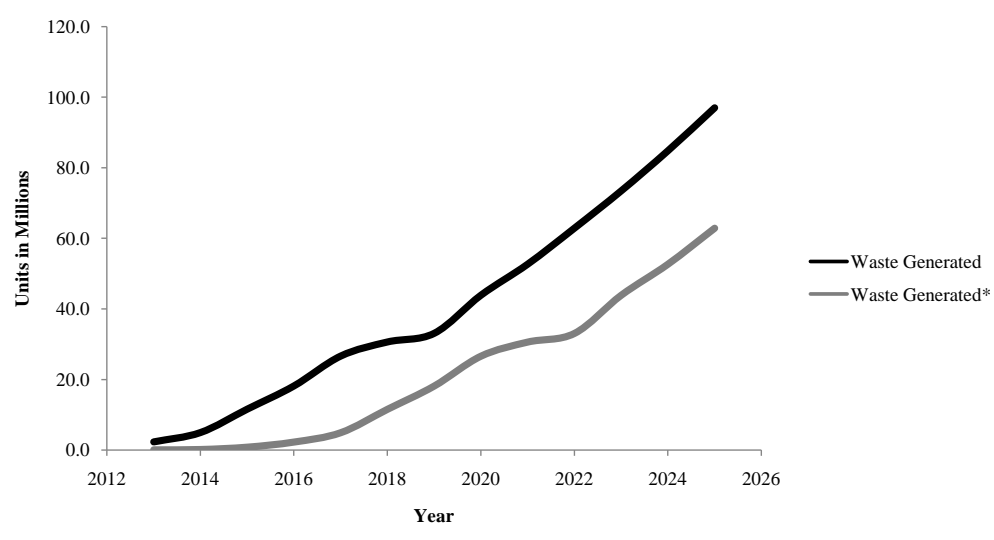

Figure 6. Sensitivity analysis flat panel TVs life span. 


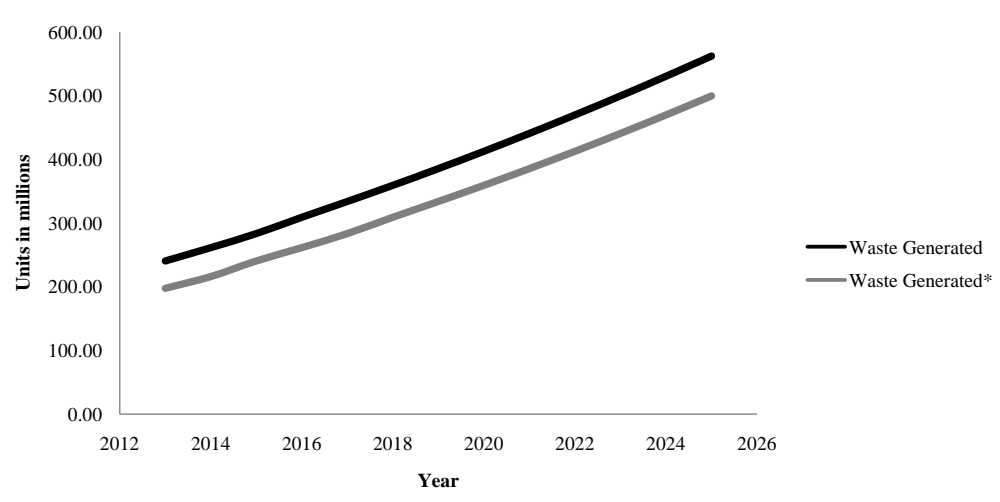

Figure 7. Sensitivity analyses for cell phones life span.

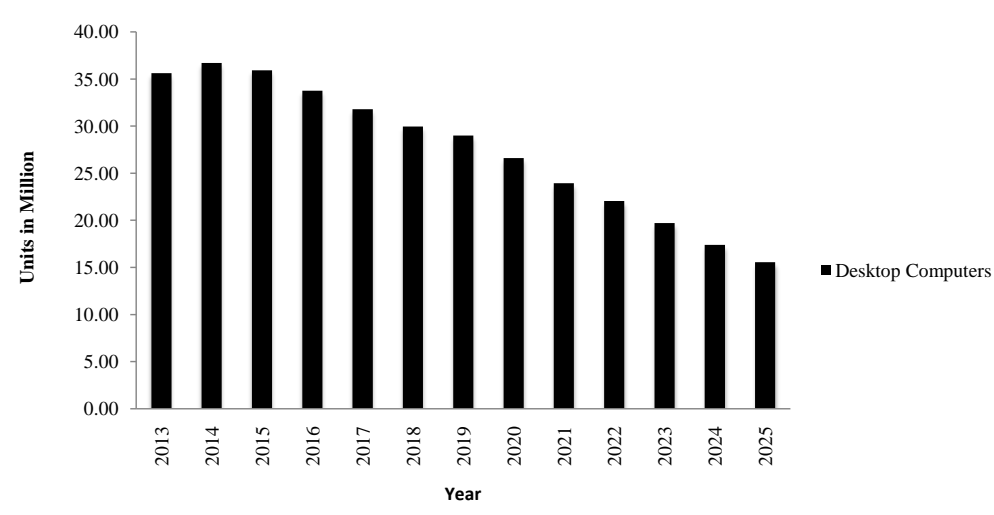

Figure 8. Desktop computer product end of the amount, model output.

Table 6. Sensitivity analyses for portable computers life span.

\begin{tabular}{lcccc}
\hline \multirow{2}{*}{ Year } & Waste generated & Waste generated $^{*}$ & Difference & Percentage of difference \\
\cline { 2 - 5 } 2013 & & Units $\times(1,000,000)$ & 41 \\
2014 & 32.4 & 19.0 & 13.4 & 41 \\
2015 & 38.4 & 22.5 & 15.9 & 38 \\
2016 & 44.2 & 27.3 & 17.0 & 37 \\
2017 & 51.4 & 32.4 & 19.0 & 35 \\
2018 & 59.2 & 38.4 & 20.8 & 35 \\
2019 & 67.6 & 44.2 & 23.4 & 32 \\
2020 & 76.1 & 51.4 & 24.7 & 30 \\
2021 & 85.1 & 59.2 & 25.9 & 29 \\
2022 & 94.6 & 67.6 & 27.0 & 27 \\
2023 & 104.8 & 76.1 & 28.7 & 26 \\
2024 & 115.5 & 85.1 & 30.4 & 25 \\
2025 & 126.8 & 94.6 & 32.1 & 24 \\
\hline
\end{tabular}

* Life span increased by 3 years.

The amount of products that can be collected for EOL management resulting from using portable computer products will increase as per Figure 9. About 138.6 million units will reach their end of life in 2025. Compared to the amount collected for EOL management estimated in this study in 2013, which is 34.2 million units, it is obvious that there will be a high increase in the collected amount of products for EOL management in the future. 
Table 7. Sensitivity analyses for flat panel TVs life span.

\begin{tabular}{lcccc}
\hline & Waste generated & Waste generated & Difference & Percentage \\
\cline { 2 - 5 } 2013 & & Units $\times(1,000,000)$ & 41 \\
2014 & 32.4 & 19.0 & 13.4 & 41 \\
2015 & 38.4 & 22.5 & 15.9 & 38 \\
2016 & 44.2 & 27.3 & 17.0 & 37 \\
2017 & 51.4 & 32.4 & 19.0 & 35 \\
2018 & 59.2 & 38.4 & 20.8 & 35 \\
2019 & 67.6 & 44.2 & 23.4 & 32 \\
2020 & 76.1 & 51.4 & 24.7 & 30 \\
2021 & 85.1 & 59.2 & 25.9 & 29 \\
2022 & 94.6 & 67.6 & 27.0 & 27 \\
2023 & 104.8 & 76.1 & 28.7 & 26 \\
2024 & 115.5 & 85.1 & 30.4 & 25 \\
2025 & 126.8 & 94.6 & 32.1 & 24 \\
\hline
\end{tabular}

*Life span increased by 3 years.

Table 8. Sensitivity analysis for cell phone life span.

\begin{tabular}{lcccc}
\hline & Waste generated & Waste generated & Difference & Percentage \\
\hline 2013 & & & $\%$ \\
2014 & 240.52 & Units $\times(1,000,000)$ & 18 \\
2015 & 261.46 & 197.50 & 43.03 & 17 \\
2016 & 283.56 & 215.97 & 45.49 & 15 \\
2017 & 309.17 & 240.52 & 43.04 & 15 \\
2018 & 333.98 & 261.46 & 47.71 & 15 \\
2019 & 359.35 & 283.56 & 50.42 & 14 \\
2020 & 385.63 & 309.17 & 50.18 & 13 \\
2021 & 412.82 & 333.98 & 51.65 & 13 \\
2022 & 440.92 & 359.35 & 53.47 & 13 \\
2023 & 469.93 & 385.63 & 55.29 & 13 \\
2024 & 499.86 & 412.82 & 57.11 & 12 \\
2025 & 530.69 & 440.92 & 58.93 & 11 \\
\hline
\end{tabular}

*Life span increased by 2 years.

Hard copy peripherals (HCPs) include printers, multifunction printers, digital copiers, and faxes. Figure 10 shows the model result; 13.4 million units will be collected for EOL management in 2025.

The model estimated about 1.7 million units and 97.0 million units will reach their end of life from CRT and flat panel monitor products, respectively, in 2025 Figure 11. 
Table 9. Sensitivity analysis for predicted sales data for portable computers product.

\begin{tabular}{|c|c|c|c|c|c|}
\hline \multirow{2}{*}{ Year } & Model EOL & $(+\% 10)^{*}$ & $(-\% 10)^{* *}$ & $\%$ for $(+\% 10)$ & $\%$ for $(-\% 10)$ \\
\hline & \multicolumn{3}{|c|}{ Units $\times(1,000,000)$} & \multicolumn{2}{|c|}{ (\%) } \\
\hline 2013 & 32.39 & 32.39 & 32.39 & 0 & 0 \\
\hline 2014 & 38.41 & 39.52 & 37.30 & 3 & -3 \\
\hline 2015 & 44.24 & 45.50 & 42.98 & 3 & -3 \\
\hline 2016 & 51.38 & 53.91 & 48.84 & 5 & -5 \\
\hline 2017 & 59.16 & 63.68 & 54.64 & 8 & -8 \\
\hline 2018 & 67.64 & 74.41 & 60.88 & 10 & -10 \\
\hline 2019 & 76.07 & 83.67 & 68.46 & 10 & -10 \\
\hline 2020 & 85.06 & 93.57 & 76.56 & 10 & -10 \\
\hline 2021 & 94.63 & 104.09 & 85.17 & 10 & -10 \\
\hline 2022 & 104.77 & 115.25 & 94.29 & 10 & -10 \\
\hline 2023 & 115.48 & 127.02 & 103.93 & 10 & -10 \\
\hline 2024 & 126.76 & 139.43 & 114.08 & 10 & -10 \\
\hline 2025 & 138.60 & 152.47 & 124.74 & 10 & -10 \\
\hline
\end{tabular}

$(+\% 10)^{*}=10 \%$ increasing in prediction sales quantity, $(-\% 10) \stackrel{* *}{=}=10 \%$ decreasing in prediction sales quantity.

Table 10. Sensitivity analysis for predicted sale data for flat panel TVs product.

\begin{tabular}{|c|c|c|c|c|c|}
\hline \multirow{2}{*}{ Year } & Model E-waste Amount & $(+\% 10)^{*}$ & $(-\% 10)^{* *}$ & $\%$ for $(+\% 10)$ & $\%$ for $(-\% 10)$ \\
\hline & \multicolumn{3}{|c|}{ Units $\times(1,000,000)$} & \multicolumn{2}{|c|}{ (\%) } \\
\hline 2013 & 2.28 & 2.28 & 2.28 & 0 & 0 \\
\hline 2014 & 4.93 & 4.93 & 4.93 & 0 & 0 \\
\hline 2015 & 11.56 & 11.56 & 11.56 & 0 & 0 \\
\hline 2016 & 18.15 & 18.15 & 18.15 & 0 & 0 \\
\hline 2017 & 26.62 & 26.62 & 26.62 & 0 & 0 \\
\hline 2018 & 30.62 & 30.62 & 30.62 & 0 & 0 \\
\hline 2019 & 33.07 & 33.07 & 33.07 & 0 & 0 \\
\hline 2020 & 43.88 & 47.61 & 40.15 & 9 & -9 \\
\hline 2021 & 52.68 & 57.61 & 47.75 & 9 & -9 \\
\hline 2022 & 62.89 & 69.18 & 56.60 & 10 & -10 \\
\hline 2023 & 73.46 & 80.80 & 66.11 & 10 & -10 \\
\hline 2024 & 84.84 & 93.32 & 76.35 & 10 & -10 \\
\hline 2025 & 97.03 & 106.73 & 87.32 & 10 & -10 \\
\hline
\end{tabular}

$(+\% 10)^{*}=10 \%$ increasing in prediction sales quantity, $(-\% 10) \stackrel{* *}{=} 10 \%$ decreasing in prediction sales quantity.

Computer accessory in this study refer to keyboards and mice. Keyboards model result shown in Figure 12 and mice in Figure 13. The predicted amount collected for EOL management from these two products in 2025 is 4.8 million units for keyboards and 1.7 million units for mice. 
Table 11. Sensitivity analyses for predicted sales data for cell phone product.

\begin{tabular}{|c|c|c|c|c|c|}
\hline \multirow{2}{*}{ Year } & Model E-waste Amount & $(+\% 10)^{*}$ & $(-\% 10)^{* *}$ & $\%$ for $(+\% 10)$ & $\%$ for $(-\% 10)$ \\
\hline & \multicolumn{3}{|c|}{ Units $\times(1,000,000)$} & \multicolumn{2}{|c|}{ (\%) } \\
\hline 2013 & 240.52 & 257.72 & 223.33 & 7 & -7 \\
\hline 2014 & 261.46 & 280.13 & 242.79 & 7 & -7 \\
\hline 2015 & 283.56 & 303.77 & 263.35 & 7 & -7 \\
\hline 2016 & 309.17 & 338.91 & 279.43 & 10 & -10 \\
\hline 2017 & 333.98 & 367.38 & 300.59 & 10 & -10 \\
\hline 2018 & 359.35 & 395.29 & 323.42 & 10 & -10 \\
\hline 2019 & 385.63 & 424.20 & 347.07 & 10 & -10 \\
\hline 2020 & 412.82 & 454.10 & 371.54 & 10 & -10 \\
\hline 2021 & 440.92 & 485.02 & 396.83 & 10 & -10 \\
\hline 2022 & 469.93 & 516.93 & 422.94 & 10 & -10 \\
\hline 2023 & 499.86 & 549.84 & 449.87 & 10 & -10 \\
\hline 2024 & 530.69 & 583.76 & 477.62 & 10 & -10 \\
\hline 2025 & 562.43 & 618.67 & 506.19 & 10 & -10 \\
\hline
\end{tabular}

$(+\% 10)^{*}=10 \%$ increasing in prediction sales quantity, $(-\% 10) \stackrel{* *}{=} 10 \%$ decreasing in prediction sales quantity.

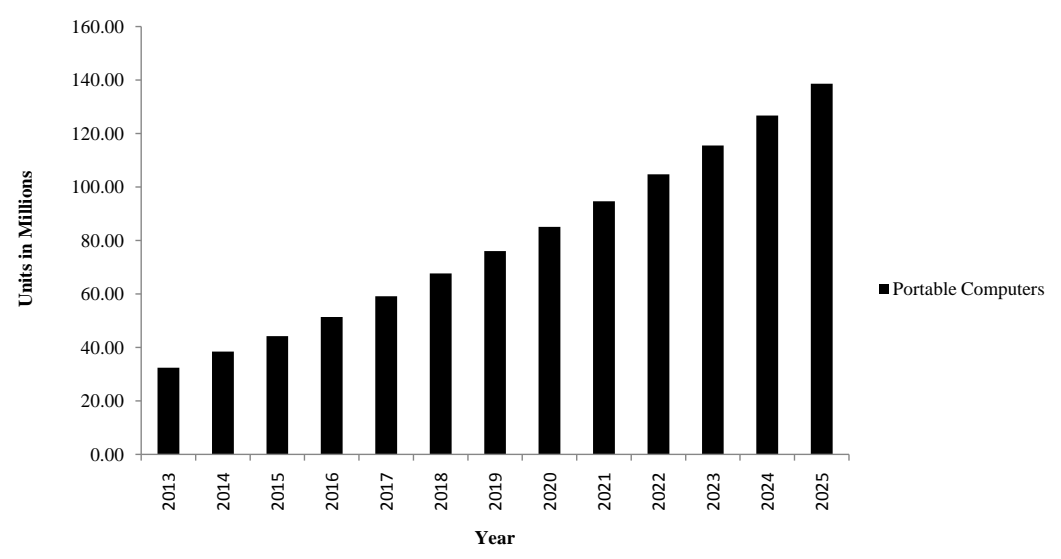

Figure 9. Portable computer end of life amount, model output.

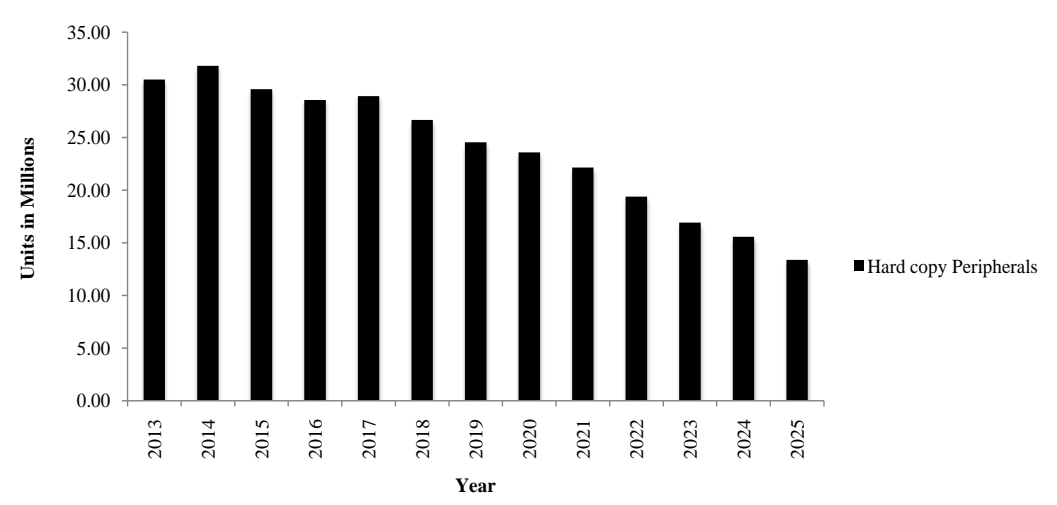

Figure 10. Hard copy peripherals end of life amount, model output. 


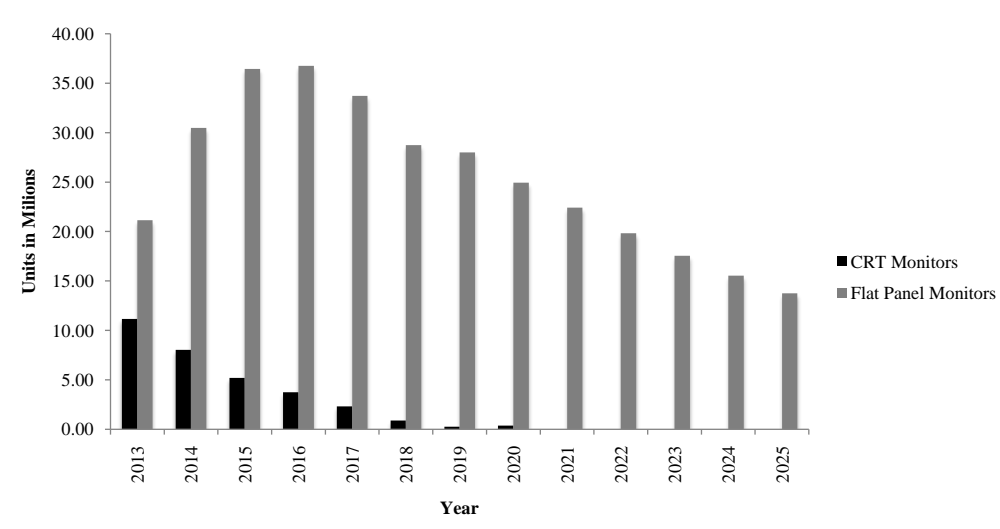

Figure 11. CRT and flat panel monitors end of life amount, model output.

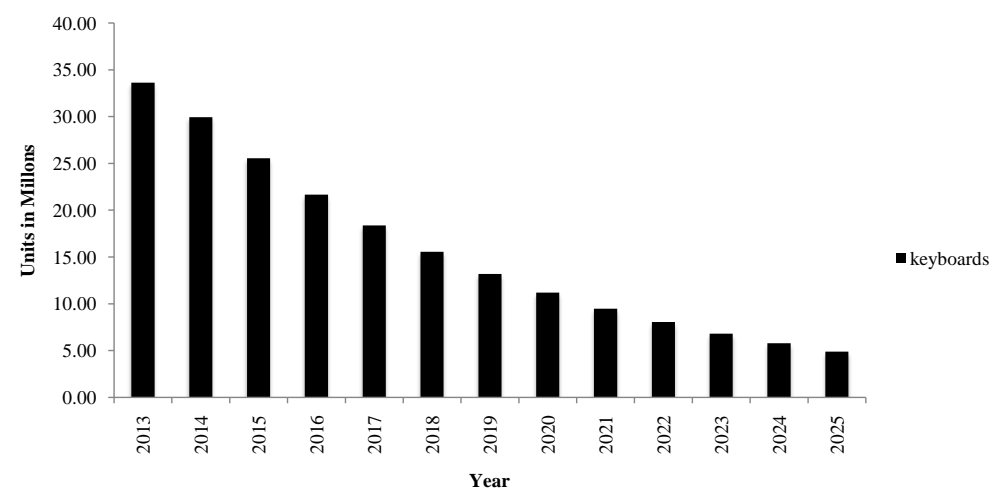

Figure 12. Keyboards end of life amount, model output.

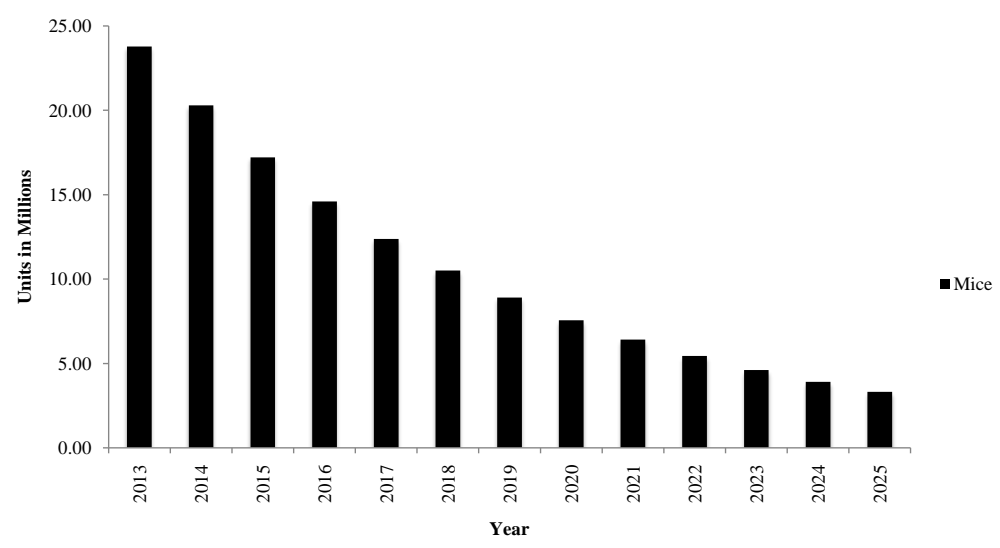

Figure 13. Mice end of life amount, model output.

Color CRT TV $<19$ inches product quantity will be collected for EOL management in 2025 is 0.13 million units as per the model result as presented in Figure 14. The future EOL amount for color CRT TV > 19 inch products estimated about 0.26 million, Figure 15 shows the result from 2013 to 2025.

Figure 16 illustrated the forecasted amount collected for EOL management from 2013 through 2025 for flat panel TV products. The collected quantity in 2025 is 97.0 million units.

Figure 17 shows the prediction e-waste amount for projectors, about 0.11 million units reach their end of life in 2025.

Prediction waste amount for monochrome, in 2013 is about 0.12 million units and will be zero from 2018 as shown in Figure 18.

The e-waste amount for cell phones shows in Figure 19. The model estimates that the amount will be col- 


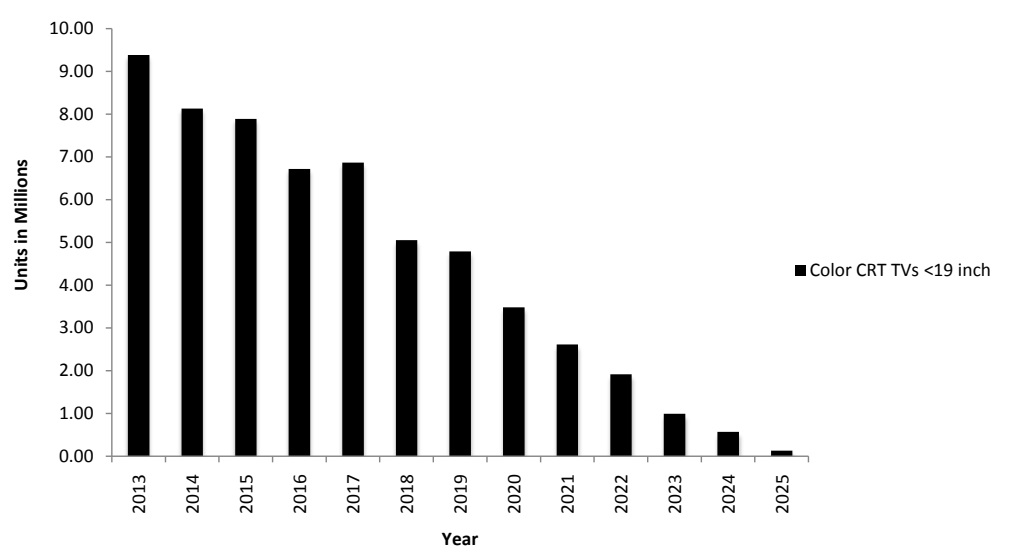

Figure 14. Color CRT TVs $<19$ inches end of life amount, model output.

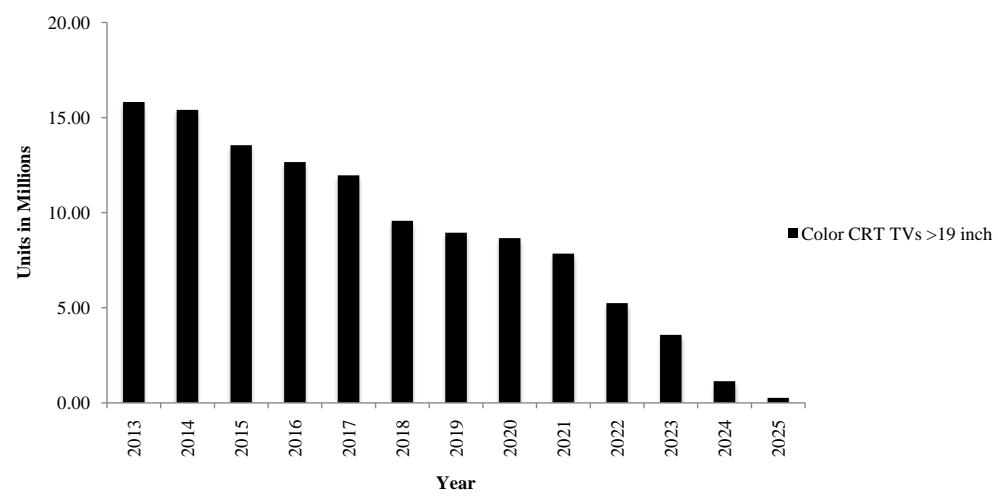

Figure 15. Color CRT TVs > 19 inches end of life amount, model output.

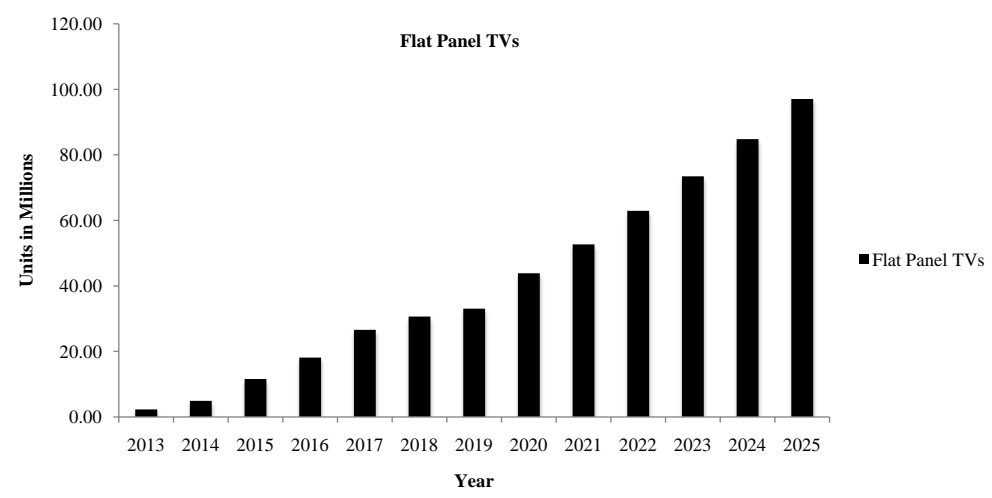

Figure 16. Flat panel TVs end of life amount, model output.

lected for EOL management is about 562.4.82 million units in 2025.

\subsection{Generation Waste Amount by Weight}

This section presents estimates of the quantity of EOL management for electronic and electrical products generated for management each year by weight. As described earlier, we developed the estimates by starting with product sales data and assuming specific life spans for each product type to represent the time between product purchase and the need for EOL management. The average weight of products is an important factor in the amount of the e-waste generation. Within some product types, such as TVs, weights vary depending on the size and type of screen. Product weights also can vary over time as technology, style, and features change [15]. The 


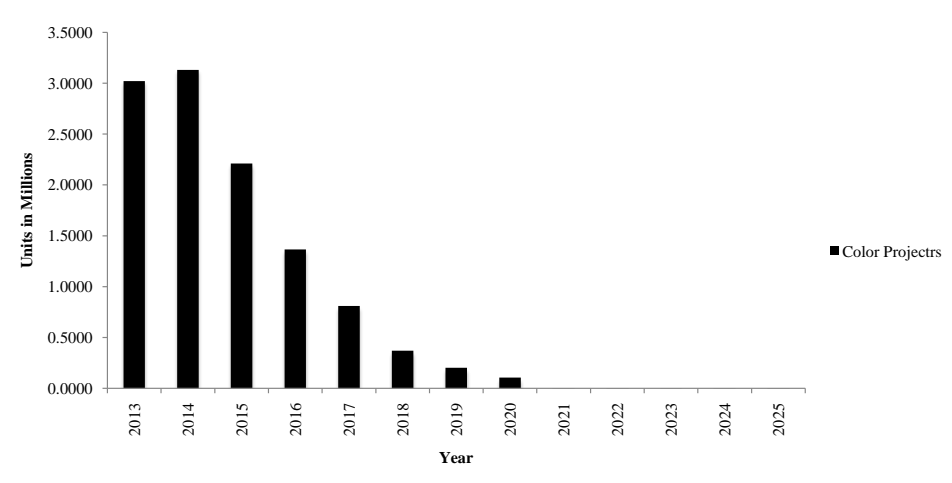

Figure 17. Projectors end of life amount, model output.

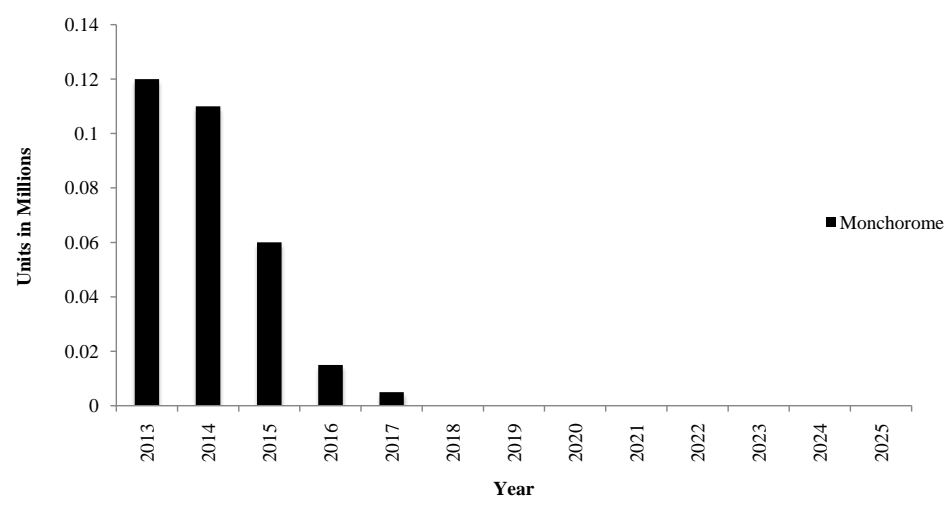

Figure 18. Monochrome end of life amount, model output.

weight of the products is adopted from [14] [15]. Tables 12-14 and Figures 20-22 presented total quantity collected for EOL management for all products. Tables 15 shows the percentage of each product collected for EOL management by units from the total amount collected for EOL management, while Table 16 shows the percentage of every product collected for EOL management by weight. The cell phone product is the highest among the all products which will be collected for EOL management by units and the lowest by weight.

\subsection{Recycling and Disposed Amount}

The majority of EOL material that is not being recycled is probably going into landfills, about $80 \%$ from the total EOL amount will go to landfills in 2025. Refer to, "even though cell phone devices are the highest product estimated in this study will be recycled still is the highest product will be land filled" followed by computers, TVs, Keyboards, mice, PC monitors and hard copy peripherals.

According to this analysis about 60.1 million units of computer products, 16.6 million units of TVs 83.3 million units from cell phones, 4.3 million units of computer displayers, 0.7 million units of keyboards and mice and 4.5 from hard copy peripherals will be recycled in 2025 as shown in "Table 17" and "Figure 21". The amount will be disposed shown in "Table 18" and "Figure 23". The total amount will be recycled is about $30 \%$ from the total amount collected for EOL management in 2025.

\section{Conclusions and Discussion}

The purpose of this study was to establish a baseline regarding the management of EOL electrical and electronic products (e-waste). The baseline data addresses televisions, cell phones, personal computers (desktops, laptops), computer displayers (CRT and flat monitors), keyboards, mice, and hard copy devices (e.g., printers, scanners, faxes) are sold between 1980 and 2025.

The quantity collected for EOL management from desktop computer products will decrease; 35.9 million units are predicted to reach their EOL in 2015 and 15.6 million units in 2025.

The collected EOL amount for portable computer products is 44.2 million units in 2015 and about 138.6 mil 


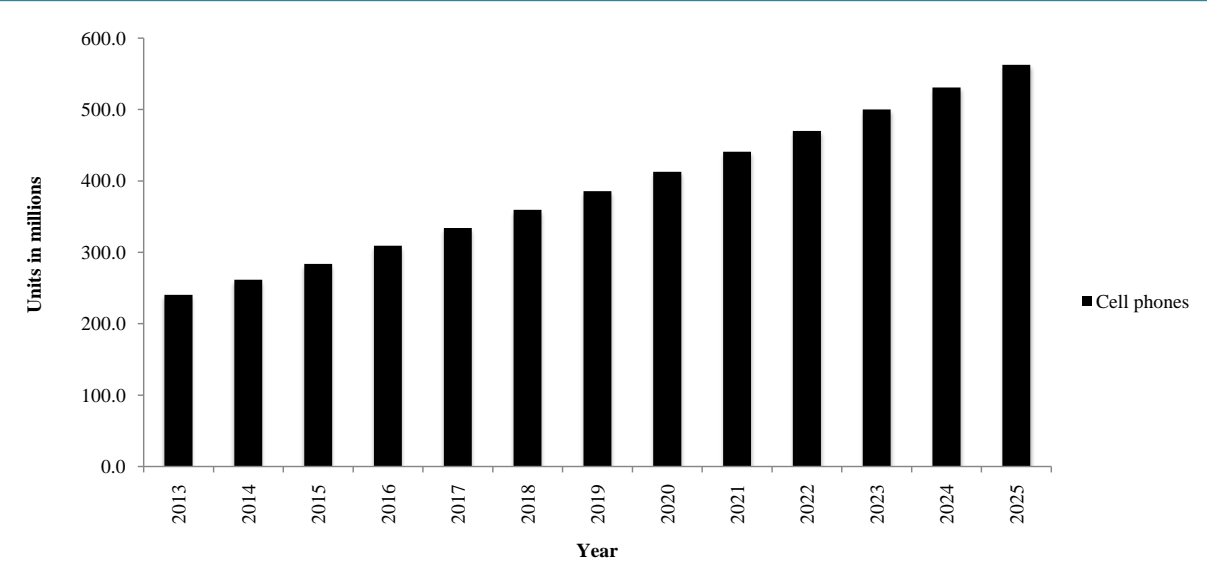

Figure 19. Cell phones end of life amount, model output.

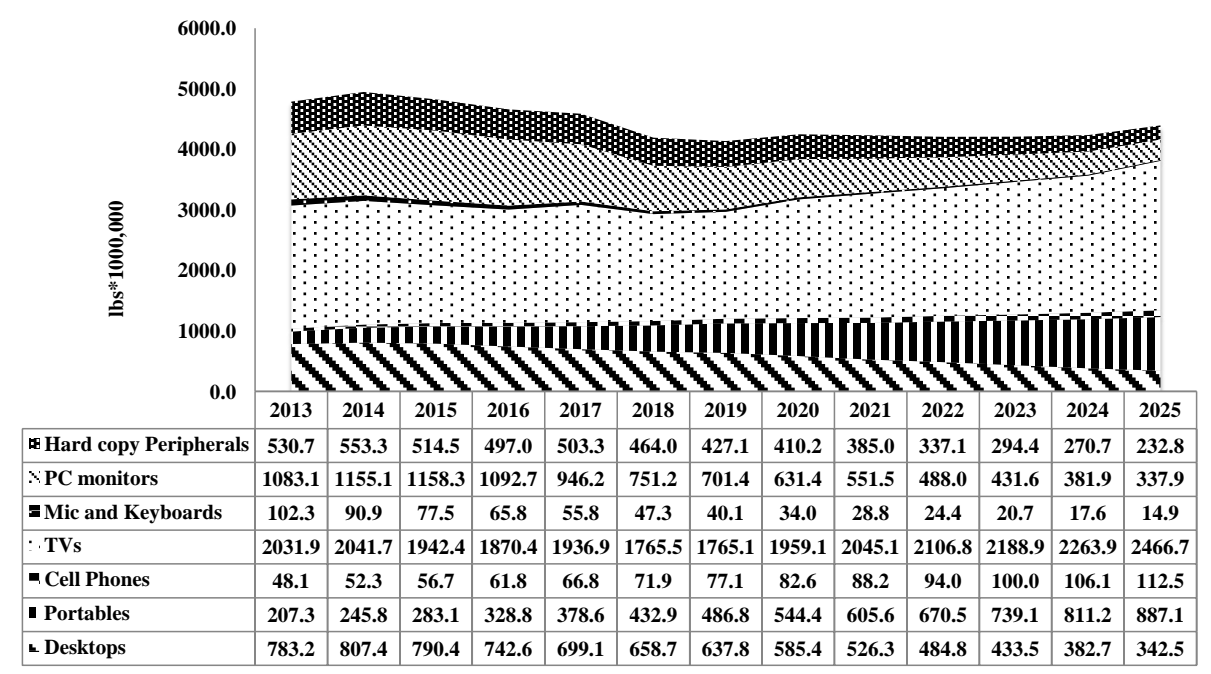

Figure 20. Waste generations amount by weight.

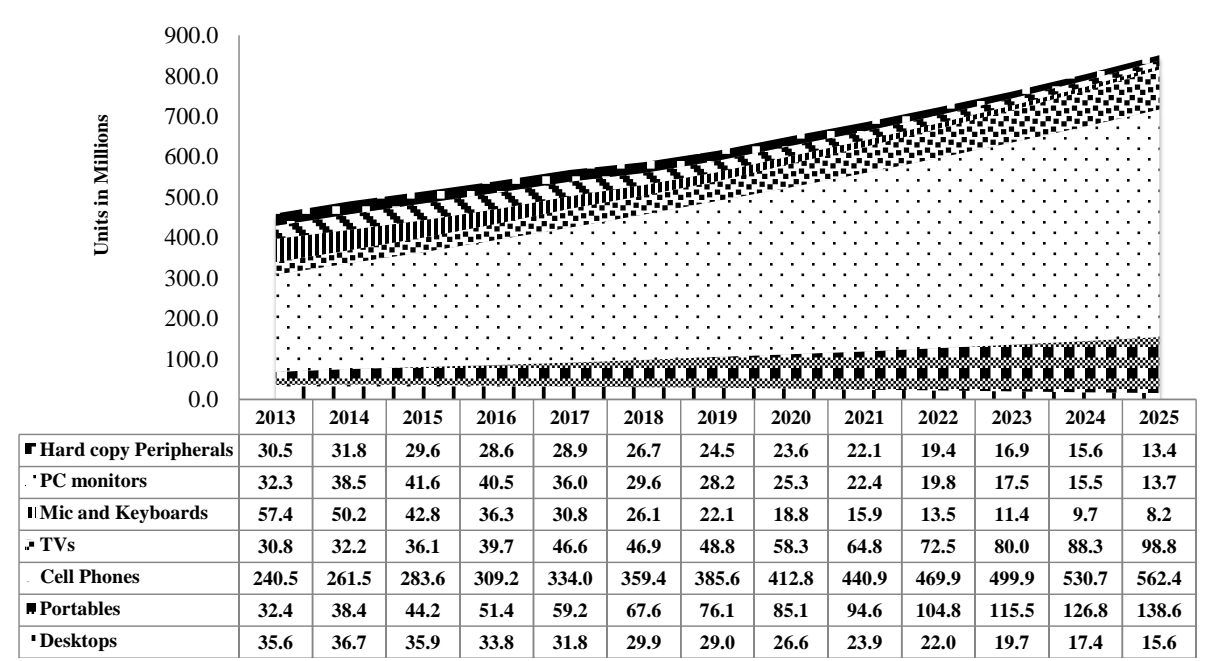

Figure 21. Waste generations amount by units.

lion units in 2025. This study shows that there will be more portable computers in the market than desktop computers in the future [16]. Therefore, there will be more e-waste generated from portable computers. We es- 


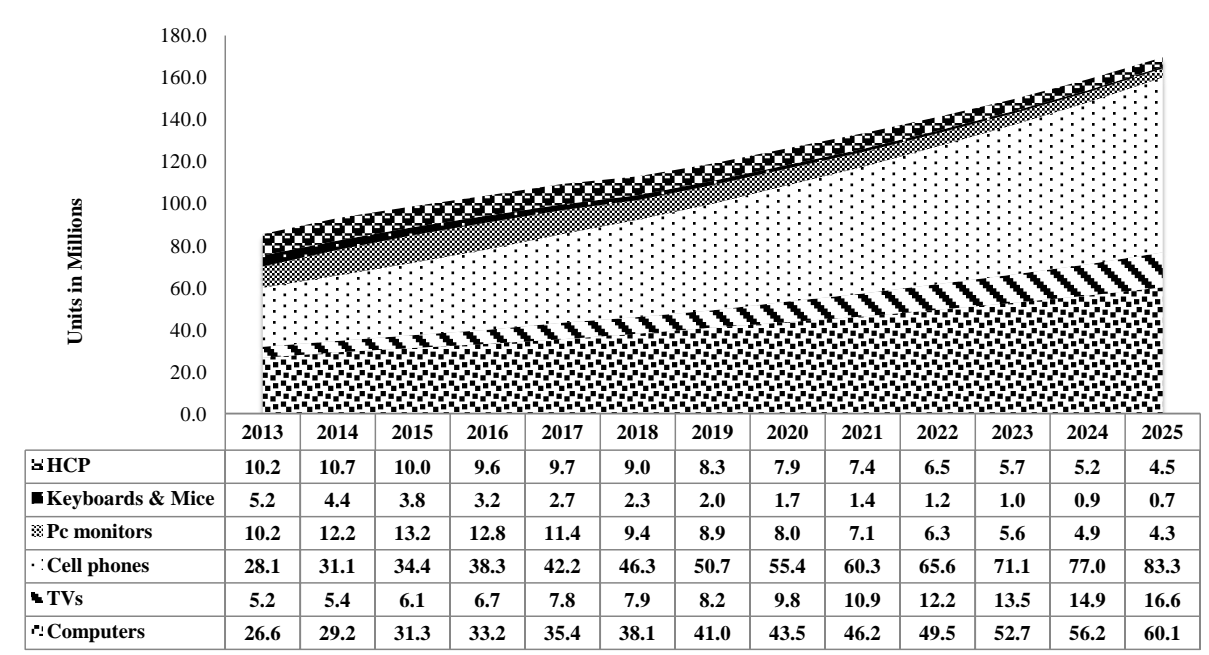

Figure 22. Recycling generation amount by units.

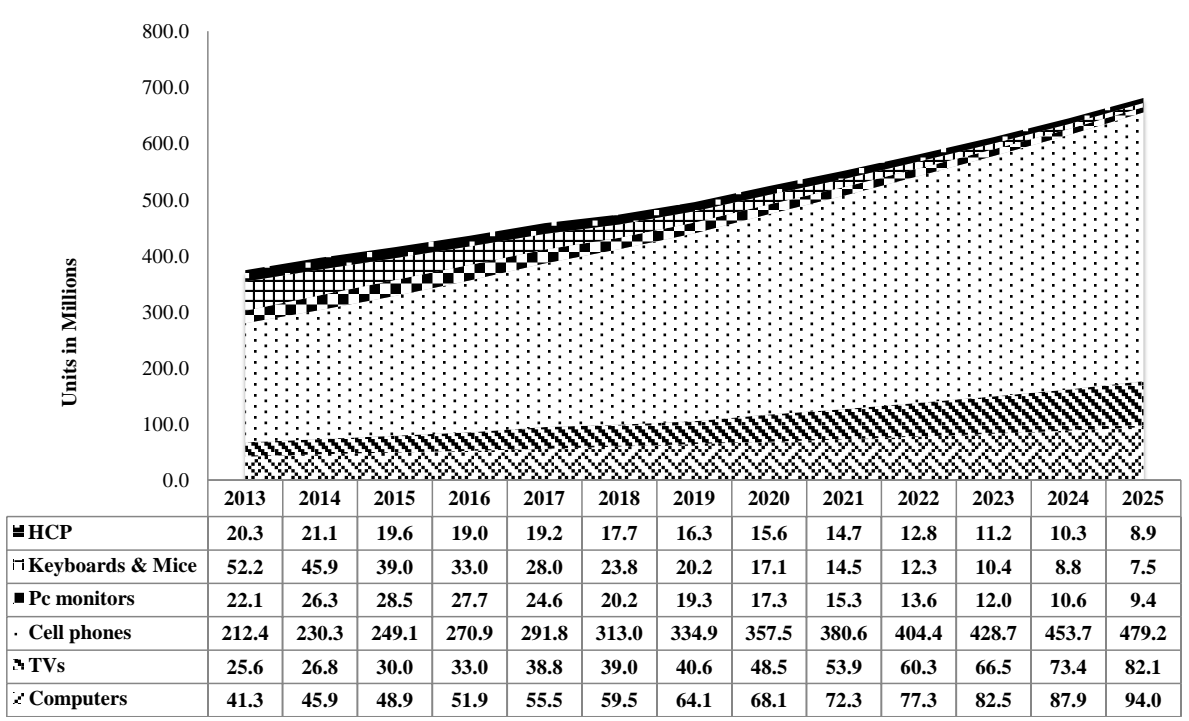

Figure 23. Disposed generation amount by units.

timate that computer products (desktops and portables) will be one of the most commonly recycled products in the future with about $7 \%$ of the total quantity collected for EOL management, and the quantity that will be disposed is about $11 \%$, unless there is a ban on dumping them in landfills.

For hard copy peripheral products, the study estimated about 13.4 million units will reach their EOL in 2025. Respectively, 4.5 million units and 8.9 million units will be recycled and disposed.

The amount collected for EOL management forecasted by the model for computer displayers is about 0.0 and 13.34 million units for CRT and flat panel monitor products, respectively, in 2025. Over the last five to seven years, flat panel monitors have taken over as the predominant monitors to be used with a computer [17]. Of these, 4.3 million units are estimated to be recycled and about 9.4 million units will be disposed.

Computer accessories in this study refer to keyboards and mice. The model result estimated about 4.9 and 3.3 million units will reach their EOL in 2025 for keyboard and mouse products, respectively. The recycled amount is less than the disposed amount; 7.5 million units will be disposed and 0.7 million units will be recycled for both products.

This study carried out predictions of EOL amounts for three types of TVs: color CRT TVs greater and less than 19 inches and flat panel TVs. The predicted sales amount estimated in this study shows that the CRT TV sales will reach 0.00 in 2016. However, the amount of e-waste generated from these two products is considera- 
Table 12. Desktops and portables computer amount collected for EOL management by weight.

\begin{tabular}{|c|c|c|c|c|c|c|}
\hline \multirow{2}{*}{ Year } & \multicolumn{2}{|c|}{ Desktops } & \multicolumn{2}{|c|}{ Portables } & \multicolumn{2}{|c|}{ Cell phones } \\
\hline & $\begin{array}{c}\text { Units } \times \\
(1,000,000)\end{array}$ & $\begin{array}{c}\text { Weight } \\
(\mathrm{lbs}) \times(1,000,000)\end{array}$ & $\begin{array}{c}\text { Units } \times \\
(1,000,000)\end{array}$ & $\begin{array}{c}\text { Weight } \\
(\mathrm{lbs}) \times(1,000,000)\end{array}$ & $\begin{array}{c}\text { Units } \times \\
(1,000,000)\end{array}$ & $\begin{array}{c}\text { Weight } \\
(\mathrm{lbs}) \times(1,000,000)\end{array}$ \\
\hline 2013 & 35.6 & 783.2 & 32.4 & 207.3 & 240.5 & 48.1 \\
\hline 2014 & 36.7 & 807.4 & 38.4 & 245.8 & 261.5 & 52.3 \\
\hline 2015 & 35.9 & 790.4 & 44.2 & 283.1 & 283.6 & 56.7 \\
\hline 2016 & 33.8 & 742.6 & 51.4 & 328.8 & 309.2 & 61.8 \\
\hline 2017 & 31.8 & 699.1 & 59.2 & 378.6 & 334.0 & 66.8 \\
\hline 2018 & 29.9 & 658.7 & 67.6 & 432.9 & 359.4 & 71.9 \\
\hline 2019 & 29.0 & 637.8 & 76.1 & 486.8 & 385.6 & 77.1 \\
\hline 2020 & 26.6 & 585.4 & 85.1 & 544.4 & 412.8 & 82.6 \\
\hline 2021 & 23.9 & 526.3 & 94.6 & 605.6 & 440.9 & 88.2 \\
\hline 2022 & 22.0 & 484.8 & 104.8 & 670.5 & 469.9 & 94.0 \\
\hline 2023 & 19.7 & 433.5 & 115.5 & 739.1 & 499.9 & 100.0 \\
\hline 2024 & 17.4 & 382.7 & 126.8 & 811.2 & 530.7 & 106.1 \\
\hline 2025 & 15.6 & 342.5 & 138.6 & 887.1 & 562.4 & 112.5 \\
\hline
\end{tabular}

Table 13. Color CRT TVs and flat panel TVs amount collected for EOL management by weight.

\begin{tabular}{|c|c|c|c|c|c|c|}
\hline \multirow{2}{*}{ Year } & \multicolumn{2}{|c|}{ Color CRT < 19 inch } & \multicolumn{2}{|c|}{ Color CRT > 19 inch } & \multicolumn{2}{|c|}{ Flat panel TVs } \\
\hline & $\begin{array}{c}\text { Units } \times \\
(1,000,000)\end{array}$ & $\begin{array}{c}\text { Weight } \\
(\text { lbs }) \times(1,000,000)\end{array}$ & $\begin{array}{c}\text { Units } \times \\
(1,000,000)\end{array}$ & $\begin{array}{c}\text { Weight } \\
(\text { lbs }) \times(1,000,000)\end{array}$ & $\begin{array}{c}\text { Units } \times \\
(1,000,000)\end{array}$ & $\begin{array}{c}\text { Weight } \\
(\text { lbs }) \times(1,000,000)\end{array}$ \\
\hline 2013 & 9.60 & 393.6 & 15.82 & 1154.5 & 2.28 & 56.1 \\
\hline 2014 & 8.61 & 353.1 & 15.41 & 1124.6 & 4.93 & 121.3 \\
\hline 2015 & 8.73 & 358.0 & 13.54 & 988.2 & 11.56 & 284.4 \\
\hline 2016 & 7.52 & 308.3 & 12.65 & 923.8 & 18.15 & 446.5 \\
\hline 2017 & 7.22 & 295.9 & 11.95 & 872.7 & 26.62 & 654.8 \\
\hline 2018 & 6.39 & 261.9 & 9.57 & 698.6 & 30.62 & 753.2 \\
\hline 2019 & 6.61 & 270.8 & 8.94 & 652.5 & 33.07 & 813.5 \\
\hline 2020 & 5.67 & 232.6 & 8.66 & 632.4 & 43.88 & 1079.4 \\
\hline 2021 & 4.30 & 176.3 & 7.85 & 572.8 & 52.68 & 1295.9 \\
\hline 2022 & 4.32 & 177.1 & 5.24 & 382.6 & 62.89 & 1547.1 \\
\hline 2023 & 2.95 & 120.8 & 3.57 & 261.0 & 73.46 & 1807.1 \\
\hline 2024 & 2.28 & 93.7 & 1.14 & 83.3 & 84.84 & 2087.0 \\
\hline 2025 & 1.49 & 61.1 & 0.26 & 18.7 & 97.03 & 2386.9 \\
\hline
\end{tabular}

ble because of the assumption of the life span and their weight. The study predicts that 0.13 million units will be collected for EOL management from color TVs $<19$ inches and 0.26 million units from color TVs $>19$ inches in 2025.

Flat panel TVs' predicted EOL quantity is 97.03 million units in 2025, which is an increase of about 8 times from 2015 and which is 11.56 million units. The total amount of TVs forecasted to be recycled is about $2.0 \%$ of 
Table 14. Projections, flat panel PC monitors amount collected for EOL management by weight.

\begin{tabular}{|c|c|c|c|c|c|c|}
\hline \multirow{2}{*}{ Year } & \multicolumn{2}{|c|}{ Projections } & \multicolumn{2}{|c|}{ Flat Panel Monitors } & \multicolumn{2}{|c|}{ CRT Monitors } \\
\hline & $\begin{array}{l}\text { Units } \times \\
(1,000,000)\end{array}$ & $\begin{array}{c}\text { Weight } \\
(\text { lbs }) \times(1,000,000)\end{array}$ & $\begin{array}{c}\text { Units } \times \\
(1,000,000)\end{array}$ & $\begin{array}{c}\text { Weight } \\
(\mathrm{lbs}) \times(1,000,000)\end{array}$ & $\begin{array}{c}\text { Units } \times \\
(1,000,000)\end{array}$ & $\begin{array}{c}\text { Weight } \\
(\mathrm{lbs}) \times(1,000,000)\end{array}$ \\
\hline 2013 & 3.0 & 422.8 & 21.13 & 519.8 & 11.15 & 563.3 \\
\hline 2014 & 3.1 & 438.2 & 30.47 & 749.6 & 8.03 & 405.5 \\
\hline 2015 & 2.2 & 309.4 & 36.45 & 896.7 & 5.18 & 261.6 \\
\hline 2016 & 1.4 & 191.2 & 36.76 & 904.3 & 3.73 & 188.4 \\
\hline 2017 & 0.8 & 113.3 & 33.72 & 829.5 & 2.31 & 116.7 \\
\hline 2018 & 0.4 & 51.9 & 28.73 & 706.8 & 0.88 & 44.4 \\
\hline 2019 & 0.2 & 28.4 & 27.99 & 688.6 & 0.25 & 12.9 \\
\hline 2020 & 0.1 & 14.7 & 24.94 & 613.4 & 0.36 & 18.0 \\
\hline 2021 & 0.0 & 0.1 & 22.41 & 551.2 & 0.00 & 0.2 \\
\hline 2022 & 0.0 & 0.0 & 19.83 & 487.8 & 0.00 & 0.2 \\
\hline 2023 & 0.0 & 0.0 & 17.54 & 431.6 & 0.00 & 0.0 \\
\hline 2024 & 0.0 & 0.0 & 15.52 & 381.9 & 0.00 & 0.0 \\
\hline 2025 & 0.0 & 0.0 & 13.74 & 337.9 & 0.00 & 0.0 \\
\hline
\end{tabular}

Table 15. Estimated for EOL Management percentage (\%) of total per units.

\begin{tabular}{|c|c|c|c|c|c|c|c|c|c|}
\hline \multirow{2}{*}{ Year } & \multirow[t]{2}{*}{ Desktops } & \multirow[t]{2}{*}{ Portables } & \multicolumn{3}{|c|}{ Cell Phones CRT TVs Flat TVs } & $\begin{array}{l}\text { Projections \& } \\
\text { Monochrome }\end{array}$ & $\begin{array}{l}\text { Mice and } \\
\text { Keyboards }\end{array}$ & PC Monitors & Total \\
\hline & & & \multicolumn{7}{|c|}{ Estimated for EOL Management Percentage of Total (\%) per Units } \\
\hline 2013 & 8 & 8 & 56 & 6 & 1 & 1 & 13 & 8 & 100 \\
\hline 2014 & 8 & 8 & 57 & 5 & 1 & 1 & 11 & 8 & 100 \\
\hline 2015 & 7 & 9 & 59 & 5 & 2 & 0 & 9 & 9 & 100 \\
\hline 2016 & 7 & 10 & 61 & 4 & 4 & 0 & 7 & 8 & 100 \\
\hline 2017 & 6 & 11 & 62 & 4 & 5 & 0 & 6 & 7 & 100 \\
\hline 2018 & 5 & 12 & 64 & 3 & 5 & 0 & 5 & 5 & 100 \\
\hline 2019 & 5 & 13 & 65 & 3 & 6 & 0 & 4 & 5 & 100 \\
\hline 2020 & 4 & 14 & 66 & 2 & 7 & 0 & 3 & 4 & 100 \\
\hline 2021 & 4 & 14 & 67 & 2 & 8 & 0 & 2 & 3 & 100 \\
\hline 2022 & 3 & 15 & 67 & 1 & 9 & 0 & 2 & 3 & 100 \\
\hline 2023 & 3 & 16 & 67 & 1 & 10 & 0 & 2 & 2 & 100 \\
\hline 2024 & 2 & 16 & 67 & 0 & 11 & 0 & 1 & 2 & 100 \\
\hline 2025 & 2 & 17 & 67 & 0 & 12 & 0 & 1 & 2 & 100 \\
\hline
\end{tabular}

the total collected amount for EOL management, and 10\% will be disposed in 2025.

Cell phone devices are the most common product that will be collected for EOL management in 2025 by units and the lowest by weight. The model predicts that 564.4 million units of cell phone devices will be ready for EOL management in 2025. Comparing this result with 2015, which is 283.6 million units, it is obvious that cell phone use will increase by double. The study estimates that 83.3 million units will be recycled and 479.2 million 
Table 16. Estimated EOL Management percentage of total (\%) per weight.

\begin{tabular}{|c|c|c|c|c|c|c|c|c|c|}
\hline \multirow{2}{*}{ Year } & Desktops & Portables & \multicolumn{3}{|c|}{ Cell Phones CRT TVs Flat TVs } & $\begin{array}{l}\text { Projections \& } \\
\text { Monochrome }\end{array}$ & $\begin{array}{c}\text { Mice and } \\
\text { Keyboards }\end{array}$ & PC Monitors & Total \\
\hline & \multicolumn{9}{|c|}{ Estimated for EOL Management percentage of total (\%) per weight } \\
\hline 2013 & 18 & 5 & 1 & 36 & 1 & 10 & 2 & 25 & 100 \\
\hline 2014 & 18 & 6 & 1 & 34 & 3 & 10 & 2 & 26 & 100 \\
\hline 2015 & 18 & 7 & 1 & 31 & 7 & 7 & 2 & 27 & 100 \\
\hline 2016 & 18 & 8 & 1 & 30 & 11 & 5 & 2 & 26 & 100 \\
\hline 2017 & 17 & 9 & 2 & 29 & 16 & 3 & 1 & 23 & 100 \\
\hline 2018 & 18 & 12 & 2 & 26 & 20 & 1 & 1 & 20 & 100 \\
\hline 2019 & 17 & 13 & 2 & 25 & 22 & 1 & 1 & 19 & 100 \\
\hline 2020 & 15 & 14 & 2 & 23 & 28 & 0 & 1 & 16 & 100 \\
\hline 2021 & 14 & 16 & 2 & 19 & 34 & 0 & 1 & 14 & 100 \\
\hline 2022 & 13 & 17 & 2 & 14 & 40 & 0 & 1 & 13 & 100 \\
\hline 2023 & 11 & 19 & 3 & 10 & 46 & 0 & 1 & 11 & 100 \\
\hline 2024 & 10 & 20 & 3 & 4 & 53 & 0 & 0 & 10 & 100 \\
\hline 2025 & 8 & 21 & 3 & 2 & 57 & 0 & 0 & 8 & 100 \\
\hline
\end{tabular}

Table 17. Recycling generation amount by units.

\begin{tabular}{|c|c|c|c|c|c|}
\hline \multirow{2}{*}{ Year } & Computers* & $\begin{array}{c}\text { PC } \\
\text { Monitors }\end{array}$ & HCP & Keyboards \& Mice & $\mathrm{TVs}^{* * *}$ \\
\hline & \multicolumn{5}{|c|}{ Units $\times(1,000,000)$} \\
\hline 2013 & 26.6 & 5.2 & 28.1 & 10.2 & 5.2 \\
\hline 2014 & 29.2 & 5.4 & 31.1 & 12.2 & 4.4 \\
\hline 2015 & 31.3 & 6.1 & 34.4 & 13.2 & 3.8 \\
\hline 2016 & 33.2 & 6.7 & 38.3 & 12.8 & 3.2 \\
\hline 2017 & 35.4 & 7.8 & 42.2 & 11.4 & 2.7 \\
\hline 2018 & 38.1 & 7.9 & 46.3 & 9.4 & 2.3 \\
\hline 2019 & 41.0 & 8.2 & 50.7 & 8.9 & 2.0 \\
\hline 2020 & 43.5 & 9.8 & 55.4 & 8.0 & 1.7 \\
\hline 2021 & 46.2 & 10.9 & 60.3 & 7.1 & 1.4 \\
\hline 2022 & 49.5 & 12.2 & 65.6 & 6.3 & 1.2 \\
\hline 2023 & 52.7 & 13.5 & 71.1 & 5.6 & 1.0 \\
\hline 2024 & 56.2 & 14.9 & 77.0 & 4.9 & 0.9 \\
\hline 2025 & 60.1 & 16.6 & 83.3 & 4.3 & 0.7 \\
\hline
\end{tabular}

"Desktops \& portable computers, ${ }^{* *} \mathrm{CRT} \&$ flat monitors, ${ }^{* * *} \mathrm{CRT}$ TVs, flat TVs, projections and monochrome.

units will be disposed. The product is the most common to be recycled but also the most common to be disposed, and the recycling is weighed at about $10 \%$ from the total amount collected for EOL management in 2025 by units.

The total amount estimated for recycling and disposal is between 169.6 and 600.1 million units for all prod 
Table 18. Disposed generation amount by units.

\begin{tabular}{|c|c|c|c|c|c|}
\hline \multirow{2}{*}{ Year } & Computers ${ }^{*}$ & PC Monitors ${ }^{* *}$ & НСР & Keyboards \& Mice & $\mathrm{TVs}^{* * *}$ \\
\hline & \multicolumn{5}{|c|}{ Units $\times(1,000,000)$} \\
\hline 2013 & 41.3 & 25.6 & 212.4 & 22.1 & 52.2 \\
\hline 2014 & 45.9 & 26.8 & 230.3 & 26.3 & 45.9 \\
\hline 2015 & 48.9 & 30.0 & 249.1 & 28.5 & 39.0 \\
\hline 2016 & 51.9 & 33.0 & 270.9 & 27.7 & 33.0 \\
\hline 2017 & 55.5 & 38.8 & 291.8 & 24.6 & 28.0 \\
\hline 2018 & 59.5 & 39.0 & 313.0 & 20.2 & 23.8 \\
\hline 2019 & 64.1 & 40.6 & 334.9 & 19.3 & 20.2 \\
\hline 2020 & 68.1 & 48.5 & 357.5 & 17.3 & 17.1 \\
\hline 2021 & 72.3 & 53.9 & 380.6 & 15.3 & 14.5 \\
\hline 2022 & 77.3 & 60.3 & 404.4 & 13.6 & 12.3 \\
\hline 2023 & 82.5 & 66.5 & 428.7 & 12.0 & 10.4 \\
\hline 2024 & 87.9 & 73.4 & 453.7 & 10.6 & 8.8 \\
\hline 2025 & 94.0 & 82.1 & 479.2 & 9.4 & 7.5 \\
\hline
\end{tabular}

"Desktops \& portable computers, ${ }^{* *}$ CRT \& flat monitors, ${ }^{* * *}$ CRT TVs, flat TVs, projections and monochrome.

ucts. The disposal amount weighed about $80.0 \%$ from the total amount collected for EOL management compared to the result of a USEPA report for 2008 [4], which stated that about $80.1 \%$. The result shows no change in the amount will go to the landfills in future and means that all the states authorities need to establish appropriate infrastructures and regulations to increase the recycling amount.

Sensitivity analysis shows that the product life span has an effect on the quantity of the e-waste that will be generated from the products under study. For example, e-waste will decrease about $20 \%$ if the life span for portable computer products increases by three years in 2025, while the sensitivity analysis for forecasted future sales indicates that the generated waste will increase or decrease according to the sales trend.

The e-waste amount per capita is estimated to be about $12.71 \mathrm{lbs}$./cap in 2025 compared to the result of a USEPA 2009 report, which shows 6.34 lbs./cap. This indicts that e-waste amount per capita in 2025 will be two times the estimated amount by USEPA in 2009 [4].

This study is based on data collected from the USEPA, assumptions for products' life span, and the percentage of products ready for EOL based on data from State of Florida and is assumed to be representative for all other states. This assumption may misrepresent product usage patterns, which could have an effect on the quantity collected for EOL management.

\section{Acknowledgements}

This work was sponsored by the Department of Energy Samuel Massie Chair of Excellence Program under Grant No. DE-NA0000718. The views and conclusions contained herein are those of the writers and should not be interpreted as necessarily representing the official policies or endorsements, either expressed or implied, of the funding agency.

\section{References}

[1] Dwivedy, M. and Mittal, R.K. (2010) Estimation of Future Outflows of E-Waste in India. Waste Management, 30, 483491. http://dx.doi.org/10.1016/j.wasman.2009.09.024

[2] Kang, H.Y. and Schoenung, J. M. (2006) Estimation of Future Outflows and Infrastructure Needed to Recycle Personal Computer Systems in California. Journal of Hazardous Materials, 137, 1165-1174. 
http://dx.doi.org/10.1016/j.jhazmat.2006.03.062

[3] Gustavo, R., Flávia, G., Martin, S., Susane, P., Renato, A. and Ribeiro, C. (2009) Diagnosis of Waste Electric and Electronic Equipment Generation in the State of Minas Gerais. Swiss Federal Laboratories for Materials Science and Technology (EMPA). (In Portuguese)

[4] United States Environmental Protection Agency (2011) Electronics Waste Management in the United States through 2009. http://www.epa.gov

[5] Steubing, B., Boni, H., Schluep, M., Silva, U. and Ludwig, C. (2010) Assessing Computer Waste Generation in Chile Using Material Flow Analysis. Waste Management, 30, 473-482. http://dx.doi.org/10.1016/j.wasman.2009.09.007

[6] Ibrahim, F.B., Adie, D.B., Giwa, A.R., Abdullahi, S.A. and Okuofu, C.A. (2013) Material Flow Analysis of Electronic Wastes (E-Wastes) in Lagos, Nigeria. Journal of Environmental Protection, 4, 1011-1017. http://dx.doi.org/10.4236/jep.2013.49117

[7] Araujo, M.G., Magrini, A., Mahler, C.F. and Bilitewski, B. (2012) A Model for Estimation of Potential Generation of Waste Electrical and Electronic Equipment in Brazil. Waste Management, 32, 335-342. http://dx.doi.org/10.1016/j.wasman.2011.09.020

[8] Oguchi, M., Kameya, T., Yagi, S. and Urano, K. (2008) Product Flow Analysis of Various Consumer Durables in Japan. Resources, Conservation and Recycling, 52, 463-480. http://dx.doi.org/10.1016/j.resconrec.2007.06.001

[9] Voet, E., Kleijn, R., Huele, R., Ishikawa, M. and Verkuijlen, E. (2002) Special Section: European Environmental History and Ecological Economics. Ecological Economics, 41, 223-234.

[10] Lau, W.K., Chung, S.S. and Zhang, C. (2013) A Material Flow Analysis on Current Electrical and Electronic Waste Disposal from Hong Kong households. Waste Management, 33, 714-721. http://dx.doi.org/10.1016/j.wasman.2012.09.007

[11] Liu, X., Tanaka, M. and Matsui, Y. (2006) Generation Amount Prediction and Material Flow Analysis of Electronic Waste: A Case Study in Beijing, China. Waste Management and Research, 24, 434-435.

[12] Kahhat, R. and Williams, E. (2012) Materials Flow Analysis of E-Waste: Domestic Flows and Exports of Used Computers from the United States. Resources, Conservation and Recycling, 67, 67-74. http://dx.doi.org/10.1016/j.resconrec.2012.07.008

[13] Morias, J.M., Van Liew, M.W., Binger, R.L., Harmel, R.D. and Veith, T.L. (2007) Model Evaluation Guidance for Systematic Qualification of Accuracy in Watershed Simulation. American Society of Agricultural and Biological Engineering, 50, 885-900.

[14] United States Protection Agency (U.S.EPA) (2007) Management of Electronic Waste in the United States: Approach Two. http://www.epa.gov

[15] United States Protection Agency (USEPA) (2008) Electronic Waste Management in United States: Approach 1. http://www.epa.gov

[16] Statista (2015) Number of Smartphone Users in the US from 2010 to 2018 (in millions). http://www.statista.com

[17] Hope, C. (2015) CRTs vs LCD. http://www.computerhope.com/ 


\section{Appendix}

Table A1. Historical sales data for computers, HCP, computer accessories and computer displayer.

\begin{tabular}{|c|c|c|c|c|c|c|c|}
\hline \multirow{3}{*}{ Year } & \multicolumn{2}{|c|}{ Computers } & \multicolumn{3}{|c|}{ Computer Peripherals \& Accessories } & \multicolumn{2}{|c|}{ Computer Displays } \\
\hline & Desktops & Portables & Hard Copy Peripherals & Mice & Keyboards & PC CRTs & PC Flat Panel \\
\hline & \multicolumn{7}{|c|}{ Units $\times(1,000,000)$} \\
\hline 1980 & 1.0 & 0.0 & 5.0 & 1.0 & 1.0 & 1.0 & 0.0 \\
\hline 1981 & 2.0 & 0.0 & 1.0 & 2.0 & 2.0 & 2.0 & 0.0 \\
\hline 1982 & 3.0 & 0.0 & 1.6 & 3.0 & 3.0 & 3.0 & 0.0 \\
\hline 1983 & 5.5 & 0.0 & 2.9 & 5.5 & 5.5 & 5.5 & 0.0 \\
\hline 1984 & 6.7 & 0.0 & 3.5 & 6.7 & 6.7 & 6.7 & 0.0 \\
\hline 1985 & 5.8 & 0.0 & 3.0 & 5.8 & 5.8 & 5.8 & 0.0 \\
\hline 1986 & 6.9 & 0.0 & 3.6 & 6.9 & 6.9 & 6.9 & 0.0 \\
\hline 1987 & 8.2 & 0.0 & 4.3 & 8.2 & 8.2 & 8.2 & 0.0 \\
\hline 1988 & 8.7 & 0.0 & 4.6 & 8.7 & 8.7 & 8.7 & 0.0 \\
\hline 1989 & 8.9 & 0.0 & 4.7 & 8.9 & 17.5 & 8.4 & 1.1 \\
\hline 1990 & 9.5 & 0.0 & 5.0 & 9.5 & 21.7 & 9.4 & 0.9 \\
\hline 1991 & 9.5 & 0.0 & 5.0 & 9.5 & 27.0 & 10.5 & 1.5 \\
\hline 1992 & 9.9 & 1.9 & 6.2 & 9.9 & 37.6 & 13.4 & 1.7 \\
\hline 1993 & 13.0 & 2.5 & 8.2 & 13.0 & 36.1 & 17.3 & 1.8 \\
\hline 1994 & 15.3 & 3.2 & 9.7 & 15.3 & 41.4 & 18.1 & 2.8 \\
\hline 1995 & 19.1 & 3.6 & 11.9 & 19.1 & 47.6 & 22.2 & 3.0 \\
\hline 1996 & 22.4 & 4.9 & 14.9 & 22.4 & 53.8 & 23.1 & 2.3 \\
\hline 1997 & 26.8 & 6.0 & 16.2 & 26.8 & 55.6 & 26.6 & 0.9 \\
\hline 1998 & 32.5 & 6.4 & 22.5 & 32.5 & 65.0 & 32.6 & 1.5 \\
\hline 1999 & 39.5 & 7.9 & 27.5 & 39.5 & 63.7 & 36.9 & 2.8 \\
\hline 2000 & 40.8 & 9.6 & 28.7 & 40.8 & 51.7 & 37.5 & 4.8 \\
\hline 2001 & 35.1 & 9.6 & 26.8 & 35.1 & 43.8 & 27.2 & 6.6 \\
\hline 2002 & 35.1 & 10.9 & 28.7 & 35.1 & 48.6 & 23.3 & 11.7 \\
\hline 2003 & 37.0 & 13.8 & 30.7 & 37.0 & 51.3 & 15.8 & 18.0 \\
\hline 2004 & 39.4 & 16.6 & 32.2 & 39.4 & 47.2 & 13.9 & 22.7 \\
\hline 2005 & 38.0 & 19.6 & 33.1 & 41.2 & 44.1 & 7.8 & 33.0 \\
\hline 2006 & 35.4 & 24.3 & 34.3 & 35.4 & 44.6 & 3.5 & 38.6 \\
\hline 2007 & 34.2 & 30.0 & 36.9 & 34.2 & 43.1 & 1.0 & 37.0 \\
\hline 2008 & 30.5 & 34.1 & 33.1 & 30.5 & 38.4 & 1.4 & 32.7 \\
\hline 2009 & 26.3 & 40.4 & 29.5 & 26.3 & 33.1 & 0.0 & 27.2 \\
\hline 2010 & 23.5 & 46.4 & 29.4 & 23.5 & 29.6 & 0.0 & 27.5 \\
\hline
\end{tabular}

Adopted from USEPA [14]. 
Table A2. Historical sales data for TVs, projections, monochromes and cell phones.

\begin{tabular}{|c|c|c|c|c|c|c|}
\hline Year & Color TVs CRT < 19 Inch & Color TVs CRT > 19 Inch & Flat Panels TVs & Projection & Monochrome & Cell Phones \\
\hline 1980 & 5.4 & 5.4 & 0.0 & 0.0 & 6.7 & 0.0 \\
\hline 1981 & 5.6 & 5.6 & 0.0 & 0.0 & 5.7 & 0.0 \\
\hline 1982 & 5.7 & 5.7 & 0.0 & 0.0 & 5.7 & 0.0 \\
\hline 1983 & 7.0 & 7.0 & 0.0 & 0.0 & 5.7 & 0.0 \\
\hline 1984 & 8.0 & 8.0 & 0.0 & 0.2 & 5.1 & 0.0 \\
\hline 1985 & 8.4 & 8.4 & 0.0 & 0.3 & 3.7 & 0.1 \\
\hline 1986 & 9.1 & 9.1 & 0.0 & 0.3 & 4.0 & 0.4 \\
\hline 1987 & 9.7 & 9.7 & 0.0 & 0.3 & 3.5 & 0.8 \\
\hline 1988 & 10.1 & 10.1 & 0.0 & 0.3 & 2.6 & 1.3 \\
\hline 1989 & 10.9 & 10.9 & 0.0 & 0.3 & 1.7 & 2.1 \\
\hline 1990 & 10.4 & 10.4 & 0.0 & 0.4 & 1.4 & 2.6 \\
\hline 1991 & 9.4 & 10.7 & 0.0 & 0.4 & 0.8 & 3.4 \\
\hline 1992 & 9.7 & 12.3 & 0.0 & 0.4 & 0.6 & 5.4 \\
\hline 1993 & 10.6 & 14.0 & 0.0 & 0.5 & 0.6 & 7.9 \\
\hline 1994 & 11.7 & 15.1 & 0.0 & 0.6 & 0.5 & 12.4 \\
\hline 1995 & 10.9 & 14.6 & 0.0 & 0.8 & 0.5 & 14.5 \\
\hline 1996 & 10.1 & 14.5 & 0.0 & 0.9 & 0.4 & 16.6 \\
\hline 1997 & 9.6 & 14.0 & 0.0 & 0.9 & 0.4 & 22.2 \\
\hline 1998 & 10.3 & 15.1 & 0.0 & 1.1 & 0.3 & 30.6 \\
\hline 1999 & 11.2 & 16.6 & 0.0 & 1.3 & 0.3 & 49.3 \\
\hline 2000 & 12.2 & 17.1 & 0.0 & 1.7 & 0.3 & 72.9 \\
\hline 2001 & 9.8 & 16.4 & 0.1 & 2.0 & 0.3 & 100.1 \\
\hline 2002 & 11.7 & 17.0 & 0.2 & 2.5 & 0.2 & 122.3 \\
\hline 2003 & 8.3 & 17.6 & 1.0 & 2.7 & 0.2 & 140.0 \\
\hline 2004 & 6.9 & 17.8 & 2.7 & 3.5 & 0.2 & 142.7 \\
\hline 2005 & 5.4 & 16.7 & 5.7 & 3.0 & 0.1 & 150.0 \\
\hline 2006 & 3.4 & 13.4 & 13.4 & 3.1 & 0.1 & 165.1 \\
\hline 2007 & 2.1 & 4.2 & 20.3 & 2.0 & 0.1 & 181.9 \\
\hline 2008 & 0.4 & 0.9 & 29.1 & 1.1 & 0.0 & 198.3 \\
\hline 2009 & 0.1 & 0.3 & 32.1 & 0.6 & 0.0 & 216.1 \\
\hline 2010 & 0.0 & 0.1 & 33.7 & 0.3 & 0.0 & 235.6 \\
\hline
\end{tabular}

Adopted from USEPA [14].

Table B. Predicted sales data for CRT TV, HCP, Projector, monochrome, mouse, keyboard and PC CRT monitor products.

\begin{tabular}{|c|c|c|c|c|c|c|c|c|c|c|c|c|c|c|c|}
\hline \multirow{2}{*}{ Year } & 2011 & 2012 & 2013 & 2014 & 2015 & 2016 & 2017 & 2018 & 2019 & 2020 & 2021 & 2022 & 2023 & 2024 & 2025 \\
\hline & \multicolumn{15}{|c|}{ Units per Millions } \\
\hline Desktops & 21.1 & 18.9 & 16.9 & 15.1 & 13.6 & 12.1 & 10.9 & 9.7 & 8.7 & 7.8 & 7.0 & 6.3 & 5.6 & 5.0 & 4.5 \\
\hline $\begin{array}{c}\text { Color CRT } \\
\text { TVs }>19 \text { Inches }\end{array}$ & 0.0 & 0.0 & 0.0 & 0.0 & 0.0 & 0.0 & 0.0 & 0.0 & 0.0 & 0.0 & 0 & 0 & 0 & 0 & 0 \\
\hline $\begin{array}{c}\text { Color CRT } \\
\text { TVs }<19 \text { Inches }\end{array}$ & 0.1 & 0.1 & 0.0 & 0.0 & 0.0 & 0.0 & 0.0 & 0.0 & 0.0 & 0.0 & 0 & 0 & 0 & 0 & 0 \\
\hline $\begin{array}{c}\text { Hardcopy } \\
\text { Peripherals }\end{array}$ & 25.3 & 21.8 & 18.7 & 16.1 & 13.8 & 11.9 & 10.2 & 8.8 & 7.6 & 6.5 & 5.6 & 4.8 & 4.1 & 3.6 & 3.1 \\
\hline Projections & 0.2 & 0.1 & 0.1 & 0.1 & 0.0 & 0.0 & 0.0 & 0.0 & 0.0 & 0.0 & 0 & 0 & 0 & 0 & 0 \\
\hline Monochrome & 0.0 & 0.0 & 0.0 & 0.0 & 0.0 & 0.0 & 0.0 & 0.0 & 0.0 & 0.0 & 0 & 0 & 0 & 0 & 0 \\
\hline Mice & 19.9 & 16.9 & 14.3 & 12.2 & 10.3 & 8.8 & 7.4 & 6.3 & 5.3 & 4.5 & 3.8 & 3.3 & 2.8 & 2.3 & 2.0 \\
\hline Keyboard & 25.1 & 21.3 & 18.1 & 15.3 & 13.0 & 11.0 & 9.3 & 7.9 & 6.7 & 5.7 & 4.8 & 4.1 & 3.5 & 2.9 & 2.5 \\
\hline $\begin{array}{l}\text { PC CRT } \\
\text { Monitors }\end{array}$ & 0.0 & 0.0 & 0.0 & 0.0 & 0.0 & 0.0 & 0.0 & 0.0 & 0.0 & 0.0 & 0 & 0 & 0 & 0 & 0 \\
\hline
\end{tabular}


Table C. Assumptions for life span and EOL percentage from the total sales for all products.

\begin{tabular}{|c|c|c|}
\hline Product & Life Span & End of Life Percentage \\
\hline \multirow{4}{*}{ Desktops } & 7-years & $25 \%$ \\
\hline & 9-years & $25 \%$ \\
\hline & 12-years & $25 \%$ \\
\hline & 15-years & $25 \%$ \\
\hline \multirow{4}{*}{ Portables } & 3-years & $20 \%$ \\
\hline & 5-years & $20 \%$ \\
\hline & 6-years & $30 \%$ \\
\hline & 7-years & $30 \%$ \\
\hline \multirow{4}{*}{ CRT TVs } & 8-years & $25 \%$ \\
\hline & 11-years & $25 \%$ \\
\hline & 15-years & $25 \%$ \\
\hline & 17-years & $25 \%$ \\
\hline \multirow{3}{*}{ Flat TVs } & 9-years & $80 \%$ \\
\hline & 10 -years & $10 \%$ \\
\hline & 11-years & $10 \%$ \\
\hline \multirow{4}{*}{ PC CRT Monitors } & 5-years & $25 \%$ \\
\hline & 8-years & $25 \%$ \\
\hline & 10 -years & $25 \%$ \\
\hline & 13-years & $25 \%$ \\
\hline \multirow{3}{*}{ PC Plat Panels } & 9-years & $80 \%$ \\
\hline & 10-year & $10 \%$ \\
\hline & 11-years & $10 \%$ \\
\hline \multirow{4}{*}{ Hard Copy Peripherals } & 4-years & $25 \%$ \\
\hline & 7-years & $25 \%$ \\
\hline & 9-years & $25 \%$ \\
\hline & 14-years & $25 \%$ \\
\hline \multirow{2}{*}{ Keyboards } & 4-years & $90 \%$ \\
\hline & 5-years & $10 \%$ \\
\hline \multirow{2}{*}{ Mice } & 3-years & $90 \%$ \\
\hline & 4-years & $10 \%$ \\
\hline \multirow{3}{*}{ Projections \& Monochrome } & 8-years & $80 \%$ \\
\hline & 9-years & $10 \%$ \\
\hline & 10 -years & $10 \%$ \\
\hline \multirow{2}{*}{ Cell Phones } & 2-years & $65 \%$ \\
\hline & 5-years & $35 \%$ \\
\hline
\end{tabular}

